\title{
Influence of Starters on Chemical, Biochemical, and Sensory Changes in Turkish White-Brined Cheese During Ripening
}

\author{
A. A. Hayaloglu, ${ }^{1}$ M. Guven, ${ }^{2}$ P. F. Fox ${ }^{3}$ and P. L. H. McSweeney ${ }^{3}$ \\ ${ }^{1}$ Department of Food Engineering, Engineering Faculty, Inonu University, TR-44280 Malatya, Turkey \\ ${ }^{2}$ Department of Food Engineering, Agricultural Faculty, Cukurova University, TR-01330 Adana, Turkey \\ ${ }^{3}$ Department of Food and Nutritional Sciences, University College, Cork, Ireland
}

\begin{abstract}
Turkish White-brined cheese was manufactured using Lactococcus strains (Lactococcus lactis ssp. lactis NCDO763 plus L. lactis ssp. cremoris SK11 and L. lactis ssp. lactis UC317 plus L. lactis ssp. cremoris HP) or without a starter culture, and ripened for $90 \mathrm{~d}$. It was found that the use of starters significantly influenced the physical, chemical, biochemical, and sensory properties of the cheeses. Chemical composition, $\mathrm{pH}$, and sensory properties of cheeses made with starter were not affected by the different starter bacteria. The levels of soluble nitrogen fractions and urea-PAGE of the $\mathrm{pH}$ 4.6-insoluble fractions were found to be significantly different at various stages of ripening. Urea-PAGE patterns of the $\mathrm{pH}$ 4.6-insoluble fractions of the cheeses showed that considerable degradation of $\alpha_{\mathrm{s} 1}$-casein occurred and that $\beta$-casein was more resistant to hydrolysis. The use of a starter culture significantly influenced the levels of $12 \%$ trichloroacetic acid-soluble nitrogen, $5 \%$ phosphotungstic acid-soluble nitrogen, free amino acids, total free fatty acids, and the peptide profiles (reverse phase-HPLC) of 70\% (vol/vol) ethanol-soluble and insoluble fractions of the $\mathrm{pH} 4.6$-soluble fraction of the cheeses. The levels of peptides in the cheeses increased during the ripening period. Principal component and hierarchical cluster analyses of electrophoretic and chromatographic results indicated that the cheeses were significantly different in terms of their peptide profiles and they were grouped based on the use and type of starter and stage of ripening. Levels of free amino acid in the cheeses differed; Leu, Glu, Phe, Lys, and Val were the most abundant amino acids. Nitrogen fractions, total free amino acids, total free fatty acids, and the levels of peptides resolved by reverse phase-HPLC increased during ripening. No significant differences were found between the sensory properties of cheeses made using a starter, but the
\end{abstract}

Received January 19, 2005.

Accepted June 7, 2005.

Corresponding author: A. A. Hayaloglu; e-mail: ahayaloglu@ inonu.edu.tr. cheese made without starter received lower scores than the cheeses made using a starter. It was found that the cheese made with strains NCDO763 plus SK11 had the best quality during ripening. It was concluded that the use of different starter bacteria caused significant differences in the quality of the cheese, and that each starter culture contributed to proteolysis to a different degree.

(Key words: White cheese, starter, Lactococcus, ripening)

Abbreviation key: EtOH-i = ethanol-insoluble, EtOH-s = ethanol-soluble, FAA = free amino acids, HCA = hierarchical cluster analysis, PCA = principal component analysis, PTA-SN $=5 \%$ phosphotungstic acid-soluble nitrogen, RP-HPLC = reverse phaseHPLC, TCA-SN $=12 \%$ TCA-soluble nitrogen, $\mathbf{W S N}=$ water-soluble nitrogen.

\section{INTRODUCTION}

Cheese ripening is a complex and dynamic biochemical process that includes protein breakdown, fat hydrolysis, and lactose metabolism (El Soda et al., 1995; McSweeney and Sousa, 2000). Proteolysis is catalyzed by proteolytic enzymes from the coagulant, milk, and bacteria (starter, nonstarter, or secondary starter; Fox, 1989). The coagulant is mainly responsible for hydrolyzing the caseins to large and intermediate-size peptides (Law et al., 1992; Lane and Fox, 1997). The enzymes originating from starter (i.e., proteinases, peptidases) play a major role in formation of small peptides and the amino acids, which serve as precursors of flavor compounds in cheese (Urbach, 1997; Broome and Limsowtin, 1998).

The primary role of starter bacteria is to produce lactic acid at a controlled rate; in addition, the bacteria affect the nonstarter microflora. Starter cultures are not used for many cheeses made in Turkey including Turkish White-brined cheese. In artisanal cheese production, the cheese is made without the deliberate addition of a starter culture; the indigenous flora of the milk contribute to ripening. Recently, the use of mixedstrain, mesophilic starter cultures, containing un- 
known genera of lactic acid bacteria commenced in the manufacture of Turkish White-brined cheese. The quality of cheese manufactured with mixed starter cultures varies widely in terms of texture and flavor.

Cheeses made using a starter containing one or more defined Lactococcus strains usually have a uniform texture due to the known biochemical activities of their microflora during cheese manufacture and ripening (Powell et al., 2002). The organisms in mixed-strain starters used in the manufacture of the cheeses belong mainly to the genera Lactococcus or Lactobacillus (Hayaloglu et al., 2002). Lactococcus species, of which $L$. lactis ssp. lactis or L. lactis ssp. cremoris are the best known, are used in cheese manufacture - these species were also found to be the predominant flora in Turkish White-brined cheese by Karakus et al. (1992).

The objective of this study was to evaluate the influence of defined starter cultures on the gross composition, proteolytic profile, and other ripening characteristics of Turkish White-brined cheese during ripening. In addition, we attempted to standardize the manufacture and quality of the cheese using a defined-strain starter.

\section{MATERIALS AND METHODS}

\section{Lactococcal Strains}

Lactococcus lactis ssp. lactis UC317, L. lactis ssp. lactis NCDO763, L. lactis ssp. cremoris HP, and L. lactis ssp. cremoris SK11 were obtained from the culture collections of University College, Cork, Ireland; Fonterra Research Centre, Palmerston North, New Zealand; and Groningen Biomolecular Science and Biotechnology Institute, Department of Genetics, University of Groningen, Haren, The Netherlands, respectively. Before use, each strain was cultivated in M17 broth (Merck, Darmstadt, Germany) at $30^{\circ} \mathrm{C}$ for $24 \mathrm{~h}$ with 2 consecutive transfers (1\%, vol/vol, inoculum). For starter propagation, the cultures were grown in reconstituted skim milk ( $10 \%$, wt/vol, heated at $90^{\circ} \mathrm{C}$ for $30 \mathrm{~min}$ ) as described by Fenelon et al. (2000).

\section{Cheese Making}

Turkish White-brined cheese was made in triplicate. In each trial, pasteurized $\left(68^{\circ} \mathrm{C}\right.$ for $\left.10 \mathrm{~min}\right)$ milk was cooled to $32^{\circ} \mathrm{C}$, divided into 3 equal parts and inoculated with a lactococcal culture at a level of $1 \%(\mathrm{wt} / \mathrm{vol})$ as follows: 1) L. lactis ssp. lactis UC317 plus L. lactis ssp. cremoris HP (317HP); 2) L. lactis ssp. lactis NCDO763 plus L. lactis ssp. cremoris SK11 (763SK11); and 3) Starter-free (SF) cheese. Calcium chloride was added to the milk at a level of $0.2 \mathrm{~g} / \mathrm{L}$. During all stages of cheese making, precautions were taken to avoid crosscontamination. The inoculated milk $\left(32^{\circ} \mathrm{C}\right)$ was held for about $30 \mathrm{~min}$ (until $\mathrm{pH}$ 6.30), and liquid calf rennet (Chr. Hansen, Copenhagen, Denmark) was added at a level of $1 \mathrm{~g}$ per $10 \mathrm{~L}$ of cheese milk (sufficient to coagulate the milk in $90 \mathrm{~min}$ ). Following coagulation, the coagulum was cut into cubes ( 2 to $3 \mathrm{~cm}$ sides) and allowed to rest for $10 \mathrm{~min}$. The curds were carefully transferred from the cheese vat into the molds. After $1 \mathrm{~h}$ of draining (without pressing), pressure was applied at room temperature $\left(21^{\circ} \mathrm{C}\right)$ for $3 \mathrm{~h}$ or until whey drainage had stopped. Then, the weights were removed and the block of cheese cut into cubes of about $7 \times 7 \times 7 \mathrm{~cm}$ with a knife; the pieces, weighing 350 to $400 \mathrm{~g}$ each, were placed in brine $(14 \% \mathrm{NaCl})$ for about $12 \mathrm{~h}$ at $21^{\circ} \mathrm{C}$. After salting, the cheese blocks were packed in cans $(16 \times 8$ $\times 8.6 \mathrm{~cm}$ ) and covered with $14 \% \mathrm{NaCl}$ brine. The cans, which contained about $1 \mathrm{~kg}$ of cheese, were closed hermetically and the cheese samples ripened at 6 to $8^{\circ} \mathrm{C}$ for $90 \mathrm{~d}$.

\section{Analysis of Cheese Samples}

Gross composition. Cheeses were analyzed at $1 \mathrm{~d}$ for moisture by the oven drying method at $102^{\circ} \mathrm{C}$ (IDF, 1982), salt by titration with $\mathrm{AgNO}_{3}$ (Bradley et al., 1993), fat by the Van Gulik method (Ardo and Polychroniadou, 1999), and total protein by the Kjeldahl method (IDF, 1993). The $\mathrm{pH}$ of cheeses was measured in a slurry prepared by macerating $10 \mathrm{~g}$ of grated cheese in $10 \mathrm{~mL}$ of deionized water. Titratable acidity was determined as grams per 100 grams of lactic acid using the method described in AOAC (1995).

Nitrogen fractions. Water-soluble nitrogen (WSN), 12\% TCA-soluble nitrogen (TCA-SN), and 5\% phosphotungstic acid-soluble nitrogen (PTA-SN) fractions were prepared by the methods of Kuchroo and Fox (1982), Polychroniadou et al. (1999), and Jarrett et al. (1982), respectively. The nitrogen content of the fractions was determined by the Kjeldahl method (IDF, 1993) and expressed as a percentage of total cheese nitrogen. All determinations were made in duplicate.

Total free amino acid content. The total concentration of free amino acids (FAA) in the cheeses was determined in triplicate by the method of Folkertsma and Fox (1992). Results were expressed as milligrams of Leu/gram of cheese. The standard Leu solutions were analyzed in triplicate and a standard curve was prepared.

Total FFA. The total concentrations of FFA in the cheeses was determined by titrating the acidity in the cheese fat with $0.05 \mathrm{~N}$ ethanolic $\mathrm{KOH}$ using the method of described by Nunez et al. (1986); results were expressed as the percentage of oleic acid in cheese fat (IDF, 1989). 
Sample preparation for urea-PAGE and reverse phase-HPLC. After ripening for 1, 15, 30, 60, or $90 \mathrm{~d}$, one cheese can from each vat was randomly selected and opened. The cheese block was divided into 4 equal parts with a knife, and 2 diagonal parts, about $200 \mathrm{~g}$ each, were grated to provide a representative sample. The $\mathrm{pH}$ 4.6-soluble and insoluble fractions were prepared using a slight modification of the method of Kuchroo and Fox (1982). A grated sample (20 g) was homogenized with $40 \mathrm{~mL}$ of distilled water for 5 min using a Colworth Stomacher 400 (Seward Laboratory, London, UK). The homogenate was adjusted to $\mathrm{pH} 4.6$ using 1.0 $M \mathrm{HCl}$, left to stand at room temperature for $30 \mathrm{~min}$ and the $\mathrm{pH}$ readjusted to $\mathrm{pH} 4.6$, if necessary. The resultant homogenate was held at $40^{\circ} \mathrm{C}$ for $1 \mathrm{~h}$, and then the $\mathrm{pH}$ 4.6-insoluble material was separated by centrifugation at $3000 \times g$ for $30 \mathrm{~min}$ in a refrigerated $\left(4^{\circ} \mathrm{C}\right)$ centrifuge (model RC5C, Sorvall, Wilmington, $\mathrm{DE}$ ). The supernatant ( $\mathrm{pH} 4.6$-soluble fraction) was filtered through glass wool and Whatman No. 113 filter paper and frozen pending peptide analysis by reverse phase-HPLC (RP-HPLC) and further fractionation. The pellet ( $\mathrm{pH}$ 4.6-insoluble fraction) was freeze-dried for analysis by urea-PAGE.

Absolute ethanol $(46.67 \mathrm{~mL})$ was added to $20-\mathrm{mL}$ aliquots of the $\mathrm{pH} 4.6$-soluble fraction to a final ethanol concentration of $70 \%$ ( $\mathrm{vol} / \mathrm{vol})$. The resultant suspension was held for $30 \mathrm{~min}$ at room temperature $\left(21^{\circ} \mathrm{C}\right)$ and then centrifuged at $3000 \times g$ for $30 \mathrm{~min}$ at $20^{\circ} \mathrm{C}$. The supernatant (containing the smaller, hydrophilic peptides that were soluble in ethanol) was filtered through Whatman No. 1 filter paper and the ethanol removed using a rotary evaporator (Bibby Sterilin Ltd., Stone, UK) at $30^{\circ} \mathrm{C}$ under vacuum. The pellet (containing the larger, more hydrophobic peptides that were insoluble in ethanol) was dispersed in distilled water and freeze-dried before analysis by RP-HPLC and urea-PAGE.

Urea-PAGE and densitometry. Urea-PAGE [4\% C (cross-linking agent as percentage of total monomer), $12.5 \% \mathrm{~T}$ (total monomer), $\mathrm{pH}$ 8.9] of the $\mathrm{pH}$ 4.6-insoluble fraction of the cheeses was performed using a Protean II XI vertical slab-gel unit (Bio-Rad Laboratories Ltd., Watford, UK) according to the method of Andrews (1983), as modified by Shalabi and Fox (1987). Freezedried samples $(10 \mathrm{mg})$ of the $\mathrm{pH} 4.6$-insoluble fraction from each sample were dissolved in $1 \mathrm{~mL}$ of electrophoresis sample buffer and vortexed (and/or sonicated, if necessary) for $1 \mathrm{~min}$ and stored at $-20^{\circ} \mathrm{C}$ until analyzed. Before electrophoresis, frozen samples were heated at $50^{\circ} \mathrm{C}$ for $5 \mathrm{~min}$ and then cooled to room temperature. A 7- $\mu \mathrm{L}$ aliquot of each sample was loaded onto the gel. Electrophoresis was performed through the stacking and separating gels at 280 and $300 \mathrm{~V}$, respectively. The gels were stained directly by the method of Blakesley and Boezi (1977) with Coomassie Brilliant Blue G-250 and destained using distilled water. After destaining, gel slabs were digitized using a scanner (HP ScanJet software, ScanJet 6300C, Hewlett Packard, Palo Alto, CA). Scans of the electrophoretograms were used to quantify bands using densitometric software (Image Master TotalLab 1D Gel analysis v1.11 software, Amersham Pharmacia Biotech, Uppsala, Sweden). The caseins and peptides were determined quantitatively by integration of peak volumes using the densitometer.

$\boldsymbol{R P}$-HPLC. Peptide profiles of $70 \%$ ethanol-soluble and insoluble fractions of the $\mathrm{pH} 4.6$-soluble fraction of samples of Turkish White-brined cheese were determined by RP-HPLC using a Varian HPLC system (Varian Associates Inc., Walnut Creek, CA). The system comprised an autosampler (model 410), a ProStar solvent delivery system with 3 pumps (model 230), a ProStar programmable multiwavelength spectrophotometer (model 310) interfaced with a PC, onto which a Varian Star Workstation 5 software package was installed for system control and data acquisition. Nucleosil RP-8 $(250 \times 4 \mathrm{~mm}, 5 \mu \mathrm{m}$ particle size, $300 \AA$ pore size) analytical and guard columns $(4.6 \times 10 \mathrm{~mm})$ (Capital HPLC Ltd., Broxburn, UK) were used. The solvents were: (A) $0.1 \%$ (vol $/ \mathrm{vol}$ ) trifluoroacetic acid (sequencing grade; Sigma, St Louis, MO) in HPLC-grade deionized water (Milli-Q system, Waters Corp., Molshem, France), and (B) $0.1 \%$ (vol/vol) trifluoroacetic acid in acetonitrile (HPLC grade, Lab-Scan Ltd., Dublin, Ireland) at a flow rate of $0.75 \mathrm{~mL} / \mathrm{min}$. Samples of freezedried $70 \%$ ethanol-soluble and insoluble subfractions of the $\mathrm{pH} 4.6$-soluble fractions were dissolved in solvent A $(10 \mathrm{mg} / \mathrm{mL})$, filtered through a $0.45-\mu \mathrm{m}$ cellulose acetate filter (Sartorius $\mathrm{GmbH}$, Gottingen, Germany); a 40- $\mu \mathrm{L}$ aliquot of filtrate was injected onto the column. The samples were eluted initially with $100 \%$ solvent A for $5 \mathrm{~min}$, then with a gradient from 0 to $50 \%$ solvent B (vol/vol) over $55 \mathrm{~min}$, maintained at $50 \%$ solvent B ( $\mathrm{vol} / \mathrm{vol}$ ) for $6 \mathrm{~min}$, followed by a linear gradient from 50 to $60 \%$ solvent $\mathrm{B}$ (vol/vol) over $4 \mathrm{~min}$, and finally with $60 \%$ solvent B (vol/vol) for $3 \mathrm{~min}$. The column was washed with $95 \%$ solvent B (vol/vol) for $5 \mathrm{~min}$, followed by equilibration with $100 \%$ solvent A for 5 min before the next injection. Elute was monitored at $214 \mathrm{~nm}$.

Determination of individual FAA. The $\mathrm{pH} 4.6$ soluble fractions were deproteinized by mixing with an equal volume of $24 \%$ (wt/vol) TCA; the mixture was allowed to stand $10 \mathrm{~min}$ and then centrifuged at 14,000 $\times g$ (Microcentaur, MSE, Fisher Scientific, Loughborough, UK) for $10 \mathrm{~min}$. The supernatant was removed and diluted with $1.2 \mathrm{M}$ sodium citrate buffer ( $\mathrm{pH} 2.2$ ) to give approximately $250 \mathrm{nmol}$ of each amino acid. The samples were diluted 1:2 with norleucine, the internal 
standard, to give approximately $125 \mathrm{nmol}$ of each amino acid residue/mL of injection solution. Samples were then analyzed on a Beckman 6300 High Performance Amino Acid Analyser (Beckman Instruments Ltd., High Wycombe, UK) fitted with a $120 \times 4 \mathrm{~mm}$ cation-exchange column ( $\mathrm{Na}^{+}$form). The individual amino acids were separated by ion-exchange chromatography with postcolumn derivatization with ninhydrin and visible colorimetric detection at $570 \mathrm{~nm}$ with the exception of proline, which was detected at $400 \mathrm{~nm}$. Results were recorded using a Minichrom data handling system (VG Data Systems, Altrincham, UK) and expressed in milligrams/100 grams of cheese.

Sensory evaluation. The cheeses were graded after $1,15,30,60$, and $90 \mathrm{~d}$ of ripening by 5 graders (from the permanent staff of the Department of Food Engineering, Cukurova University, Turkey) who were experienced cheese tasters and familiar with Turkish Whitebrined cheese. They graded the cheeses for appearance (scale 0 to 20), body and texture (scale 0 to 35), odor (scale 0 to 10), and flavor (scale 0 to 35), according to the Turkish Standards for Turkish White-brined cheese, No 591 (TSE, 1995). Coded cheese samples were removed from the refrigerator about $1 \mathrm{~h}$ before evaluation and kept at room temperature. Approximately 400 $\mathrm{g}$ of cheese was presented to each panel member. Water and bread were also provided to the panelists to rinse their mouths between samples. Graders were requested to rank the samples in order according to their overall quality or general acceptability.

\section{Statistical Analyses}

A randomized complete block design which incorporated 3 treatments (cheeses $\mathrm{A}, \mathrm{B}$, or $\mathrm{C}$ ), 5 ripening periods $(1,15,30,60$, or $90 \mathrm{~d}$ ), and 3 blocks (trials) was used to analyze the response variables relating to cheese composition, proteolysis, lipolysis, and sensory data. Analysis of variance was performed using the GLM procedure of SAS (SAS Institute, 1995) where the effect of treatment and replicates were estimated for response variables. Duncan's multiple-comparison test was used as a guide for pair comparisons of treatment means. The level of significance of differences between treatments was determined at $P<0.05$.

Data from urea-PAGE gels of the $\mathrm{pH}$ 4.6-insoluble fractions were analyzed using multivariate statistical techniques. Similar bands were recognized visually and matched as described by McSweeney et al. (1994) in the urea-PAGE gels. Volumes of corresponding bands were measured densitometrically and used as data for statistical analysis using principal components analysis (PCA). Reverse phase-HPLC chromatograms of the $70 \%$ ethanol-soluble or insoluble fractions were ana-

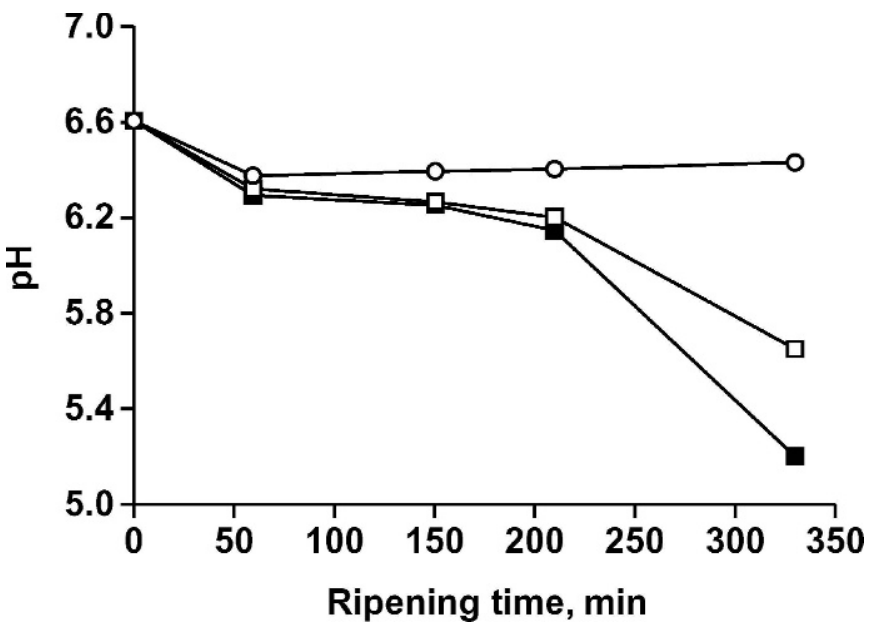

Figure 1. $\mathrm{pH}$ development during the manufacture of Turkish White-brined cheese, made with starter culture systems 317HP (ם), 763SK11 ( $\square$ ), and SF (O). Cheeses: $\mathrm{SF}=$ starter free; 763SK11 $=L$. lactis ssp. lactis NCDO763 plus L. lactis $\mathrm{ssp}$. cremoris SK11; 317HP = L. lactis ssp. lactis UC317 plus L. lactis ssp. cremoris HP.

lyzed by multivariate statistical analyses. Data for multivariate statistical analysis of the RP-HPLC chromatograms were obtained by visually recognizing similar peaks in the chromatograms and using the peak heights as variables in the analysis. The peak heights were obtained by converting the corresponding chromatogram to an ASCII file. Principal components analysis was performed using the covariance matrix and varimax rotation, and hierarchical cluster analysis (HCA) was performed using Euclidean distance and average linkage without standardizing the variables (Pripp et al., 1999). Statistical analysis was performed using SPSS version 11.0 (SPSS Inc., Chicago, IL).

\section{RESULTS AND DISCUSSION}

\section{pH Changes During Cheese Manufacture}

Acid development is a very important criterion in the manufacture of cheeses ripened under brine due to the inhibitory effect of lactic acid on undesirable microorganisms, and curd stability during brining (Abd ElSalam et al., 1993; Bintis and Papademas, 2002). Changes in the $\mathrm{pH}$ of the cheese curd during cheese making are shown in Figure 1. The cheeses made from milk inoculated with a starter exhibited similar $\mathrm{pH}$ profiles during cheese manufacture. In SF cheeses, the $\mathrm{pH}$ of the curds after coagulation were the same as in the other cheeses, but after $60 \mathrm{~min}$, there was no further acid development in SF cheeses until the end of cheese making. After $210 \mathrm{~min}$, the $\mathrm{pH}$ of the $317 \mathrm{HP}$ and 763SK11 cheeses decreased sharply to 5.21 and 5.65, respectively. The $\mathrm{pH}$ of the cheeses made with a starter 
Table 1. Chemical composition and $\mathrm{pH}$ values of Turkish White-brined cheeses at 1, 15, 30, 60, and $90 \mathrm{~d}$.

\begin{tabular}{|c|c|c|c|c|}
\hline & \multirow{2}{*}{$\begin{array}{l}\text { Age of } \\
\text { cheese, } d\end{array}$} & \multicolumn{3}{|c|}{ Cheese $^{1}$} \\
\hline & & $\mathrm{SF}$ & 763SK11 & $317 \mathrm{HP}$ \\
\hline $\mathrm{pH}$ & $\begin{array}{r}1 \\
15 \\
30 \\
60 \\
90\end{array}$ & $\begin{array}{l}6.04 \pm 0.05^{\mathrm{a}} \\
5.59 \pm 0.05^{\mathrm{a}} \\
5.48 \pm 0.06^{\mathrm{a}} \\
5.33 \pm 0.15^{\mathrm{a}} \\
5.19 \pm 0.18^{\mathrm{a}}\end{array}$ & $\begin{array}{l}4.97 \pm 0.13^{\mathrm{b}} \\
4.94 \pm 0.05^{\mathrm{b}} \\
4.81 \pm 0.06^{\mathrm{b}} \\
4.80 \pm 0.06^{\mathrm{b}} \\
4.78 \pm 0.06^{\mathrm{b}}\end{array}$ & $\begin{array}{l}4.84 \pm 0.06^{\mathrm{b}} \\
4.85 \pm 0.03^{\mathrm{b}} \\
4.85 \pm 0.02^{\mathrm{b}} \\
4.86 \pm 0.03^{\mathrm{b}} \\
4.87 \pm 0.04^{\mathrm{b}}\end{array}$ \\
\hline Titratable acidity $^{2}$ & $\begin{array}{r}1 \\
15 \\
30 \\
60 \\
90\end{array}$ & $\begin{array}{l}0.51 \pm 0.05^{\mathrm{a}} \\
0.73 \pm 0.05^{\mathrm{a}} \\
1.03 \pm 0.06^{\mathrm{a}} \\
1.23 \pm 0.15^{\mathrm{a}} \\
1.21 \pm 0.18^{\mathrm{a}}\end{array}$ & $\begin{array}{l}1.55 \pm 0.05^{\mathrm{b}} \\
1.52 \pm 0.07^{\mathrm{b}} \\
2.02 \pm 0.13^{\mathrm{b}} \\
1.98 \pm 0.08^{\mathrm{b}} \\
2.07 \pm 0.12^{\mathrm{b}}\end{array}$ & $\begin{array}{l}1.68 \pm 0.07^{\mathrm{b}} \\
1.72 \pm 0.12^{\mathrm{b}} \\
1.90 \pm 0.15^{\mathrm{b}} \\
1.84 \pm 0.01^{\mathrm{b}} \\
1.73 \pm 0.19^{\mathrm{b}}\end{array}$ \\
\hline Moisture, \% & $\begin{array}{r}1 \\
15 \\
30 \\
60 \\
90\end{array}$ & $\begin{array}{l}57.39 \pm 1.02^{\mathrm{a}} \\
57.56 \pm 0.74^{\mathrm{a}} \\
58.63 \pm 0.47^{\mathrm{a}} \\
60.53 \pm 0.61^{\mathrm{a}} \\
60.08 \pm 0.76^{\mathrm{a}}\end{array}$ & $\begin{array}{l}50.81 \pm 1.30^{\mathrm{b}} \\
50.87 \pm 0.75^{\mathrm{b}} \\
51.74 \pm 1.45^{\mathrm{b}} \\
52.21 \pm 0.79^{\mathrm{b}} \\
52.40 \pm 0.98^{\mathrm{b}}\end{array}$ & $\begin{array}{l}50.47 \pm 0.61^{b} \\
50.13 \pm 0.70^{b} \\
51.16 \pm 1.03^{b} \\
51.63 \pm 0.96^{b} \\
51.75 \pm 0.88^{b}\end{array}$ \\
\hline Fat in DM, \% & $\begin{array}{r}1 \\
15 \\
30 \\
60 \\
90\end{array}$ & $\begin{array}{l}48.88 \pm 1.38^{\mathrm{a}} \\
49.69 \pm 1.18^{\mathrm{a}} \\
49.57 \pm 0.56^{\mathrm{a}} \\
48.04 \pm 0.58^{\mathrm{a}} \\
51.76 \pm 0.85^{\mathrm{a}}\end{array}$ & $\begin{array}{l}50.43 \pm 1.03^{\mathrm{a}} \\
50.69 \pm 1.00^{\mathrm{a}} \\
50.12 \pm 1.43^{\mathrm{a}} \\
49.51 \pm 1.57^{\mathrm{a}} \\
52.89 \pm 0.90^{\mathrm{a}}\end{array}$ & $\begin{array}{l}50.10 \pm 1.73^{\mathrm{a}} \\
50.96 \pm 1.23^{\mathrm{a}} \\
49.64 \pm 0.27^{\mathrm{a}} \\
50.49 \pm 0.38^{\mathrm{a}} \\
51.11 \pm 0.49^{\mathrm{a}}\end{array}$ \\
\hline Salt-in-moisture, $\%$ & $\begin{array}{r}1 \\
15 \\
30 \\
60 \\
90\end{array}$ & $\begin{array}{r}8.88 \pm 0.53^{\mathrm{a}} \\
10.06 \pm 0.38^{\mathrm{a}} \\
6.91 \pm 0.63^{\mathrm{a}} \\
7.21 \pm 0.54^{\mathrm{a}} \\
7.87 \pm 0.66^{\mathrm{a}}\end{array}$ & $\begin{aligned} & 10.01 \pm 0.30^{\mathrm{b}} \\
& 11.02 \pm 0.50^{\mathrm{b}} \\
& 8.34 \pm 0.39^{\mathrm{ab}} \\
& 8.42 \pm 0.74^{\mathrm{ab}} \\
& 8.38 \pm 0.72^{\mathrm{b}}\end{aligned}$ & $\begin{array}{r}10.28 \pm 0.30^{\mathrm{b}} \\
10.53 \pm 0.29^{\mathrm{b}} \\
9.05 \pm 0.60^{\mathrm{a}} \\
9.29 \pm 0.56^{\mathrm{b}} \\
8.54 \pm 0.33^{\mathrm{b}}\end{array}$ \\
\hline Protein, \% & $\begin{array}{r}1 \\
15 \\
30 \\
60 \\
90\end{array}$ & $\begin{array}{l}12.78 \pm 0.02^{\mathrm{a}} \\
12.84 \pm 0.62^{\mathrm{a}} \\
12.95 \pm 0.46^{\mathrm{a}} \\
12.89 \pm 0.34^{\mathrm{a}} \\
12.95 \pm 0.85^{\mathrm{a}}\end{array}$ & $\begin{array}{l}17.27 \pm 0.85^{\mathrm{b}} \\
17.29 \pm 0.31^{\mathrm{b}} \\
17.25 \pm 0.57^{\mathrm{b}} \\
16.10 \pm 0.36^{\mathrm{b}} \\
15.10 \pm 0.17^{\mathrm{b}}\end{array}$ & $\begin{array}{l}16.97 \pm 0.42^{b} \\
16.74 \pm 0.44^{b} \\
16.38 \pm 0.61^{b} \\
15.84 \pm 0.80^{b} \\
16.10 \pm 0.14^{b}\end{array}$ \\
\hline
\end{tabular}

\footnotetext{
${ }^{\mathrm{a}, \mathrm{b}}$ Means in the same row having different letters are significantly different $(P<0.05)$.

${ }^{1}$ Cheeses: $\mathrm{SF}=$ starter free; $763 \mathrm{SK} 11=$ L. lactis ssp. lactis NCDO763 plus L. lactis ssp. cremoris SK11; $317 \mathrm{HP}=$ L. lactis ssp. lactis UC317 plus L. lactis ssp. cremoris HP.

${ }^{2}$ Titratable acidity expressed as percentage of lactic acid.
}

culture continued to decrease during preripening and reached $\mathrm{pH} 5.0$ by the next morning. However, the $\mathrm{pH}$ of $\mathrm{SF}$ cheeses remained $>5.0$.

\section{Gross Composition and $\mathrm{pH}$}

The chemical composition of Turkish White-brined cheeses during ripening is shown in Table 1 . There were no significant differences in gross composition between the 2 cheeses made using different starter strains. However, SF cheeses were significantly different from $317 \mathrm{HP}$ or $763 \mathrm{SK} 11$ cheeses in terms of gross composition and curd acidity. Acidification with a starter culture influenced curd acidity, which caused differences in the syneresis of the curd during cheese making. The initial $\mathrm{pH}$ of the SF cheeses was 6.04 , whereas that in the 763SK11 and 317HP cheeses was 4.97 and 4.84, respectively. The $\mathrm{pH}$ of the $\mathrm{SF}$ cheeses decreased during ripening (from 6.04 on $d 1$ to 5.19 on d 90), whereas the $\mathrm{pH}$ difference of cheese made using a starter culture was not significant $(P>0.05)$ during ripening. Because of the higher initial $\mathrm{pH}$ of the SF cheese compared with that of starter-added cheeses and the action of native microflora or nonstarter lactic acid bacteria on lactose in the SF cheese, a rapid decrease was seen in the SF cheese during ripening. No major differences were noted in terms of fat-in-DM content, with the level slightly lower in the SF cheeses than in other cheeses due to its higher moisture content. The mean moisture content of the SF cheese samples was significantly higher $(P<0.05)$ than that of the $763 \mathrm{SK} 11$ or $317 \mathrm{HP}$ cheese samples. The total protein content of the SF cheeses was significantly lower than that of the other cheeses during the ripening period. The difference can be attributed to the concentration effect on compositional parameters; the level of moisture was high in the SF cheese (Table 1). Differences in $\mathrm{pH}$ between the cheeses made with starter cultures and SF cheeses resulted in significant differences in the levels of cheese moisture or salt-in-moisture as well as lactic acid content. The salt-in-moisture content of all cheeses was higher than would be expected for Turkish White- 


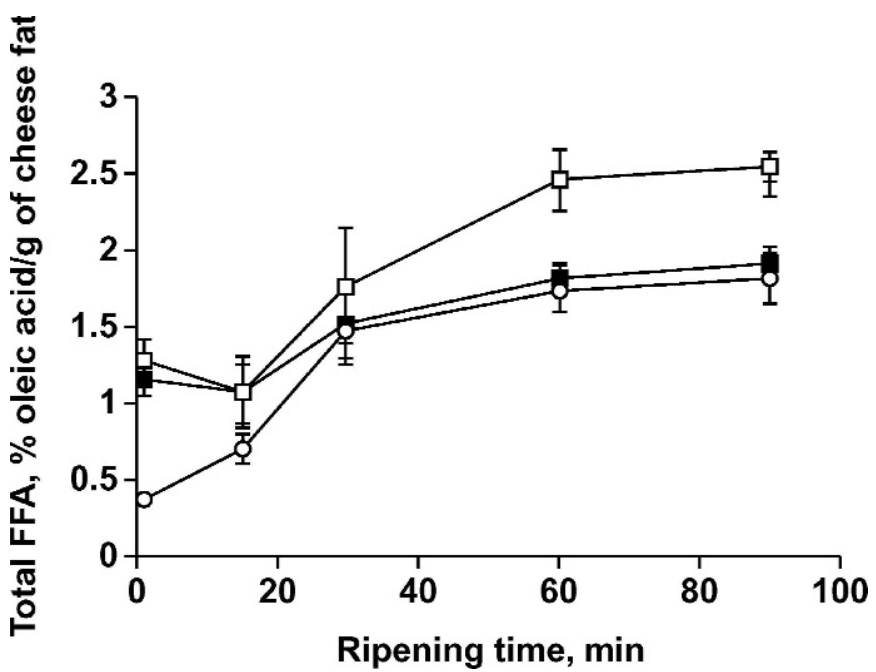

Figure 2. Formation of total free fatty acids during ripening of Turkish white-brined cheeses made with starter culture systems 317HP (匹), 763SK11 ( $\square$ ), and SF $(\bigcirc)$. Cheeses: SF = starter free; $763 \mathrm{SK} 11=$ L. lactis $\mathrm{ssp}$. lactis NCDO763 plus L. lactis ssp. cremoris SK11; 317HP = L. lactis ssp. lactis UC317 plus L. lactis ssp. cremoris $\mathrm{HP}$.

brined cheese; however, protein and fat-in-DM content of the cheeses were in the normal ranges. No major differences were observed between the 763SK11 and $317 \mathrm{HP}$ cheeses in terms of $\mathrm{pH}$ or gross composition. The results confirmed the findings of Litopoulou-Tzanetaki et al. (1993), Karakus and Alperden (1995), Pappas et al. (1996), and Pappa and Anifantakis (2001).

\section{Total FFA}

The extent of lipolysis in the cheeses during ripening is shown in Figure 2. The total concentration of FFA in all cheeses increased during ripening, except at 15 $\mathrm{d}$ for cheeses made with a starter culture. At 1 and 15 $d$, the SF cheeses contained significantly lower levels of FFA than the other cheeses, whereas the level of FFA was higher in the 763 SK11 cheeses than in the $\mathrm{SF}$ or $317 \mathrm{HP}$ cheeses after $60 \mathrm{~d}$ of ripening. The SF cheeses had the lowest level of lipolysis during aging. The results indicate that each starter culture caused a different level of lipolysis in cheese. This observation is in agreement with the results of Awad et al. (1999), who found that starter-free cheeses had the lowest FFA index, and starter strains contributed to lipolysis to different extents. Kilic et al. (1998) reported that Tulum cheese made with a starter had a higher level of FFA than starter-free Tulum cheeses during ripening, probably due to lipase activity of starter bacteria.

\section{Nitrogen Fractions}

WSN. The concentration of WSN as a percentage of total $\mathrm{N}$ in all cheeses increased significantly $(P<0.01)$ during ripening (Table 2). The level of WSN was significantly lower in SF cheeses at d 1 or 15 than in the 763SK11 and 317HP cheeses; however, WSN increased sharply at d 90 in SF cheeses, reaching a value of $23.68 \%$, whereas this fraction in the 763SK11 and $317 \mathrm{HP}$ cheeses was 20.85 and $19.69 \%$, respectively. At the end of ripening, the level of WSN was highest in SF cheeses, which is attributed to the proteolytic activity of nonstarter lactic acid bacteria that dominate toward the end of ripening (Crow et al., 1993; Moatsou et al., 1999), and to plasmin activity due to the high $\mathrm{pH}$ of cheese (Rank et al., 1985; Lynch et al., 1997; Michaelidou et al., 1998; Fox et al., 2000). The different starter cultures had no significant effect on the level of WSN in the cheeses at any stages of ripening, except at $d 1$ and 30. This indicates that the starter organisms do not make a direct contribution to the WSN content in cheese (Fox et al., 1993; Madkor et al., 2000).

TCA-SN. The content of TCA-SN in all cheeses increased linearly at a significant level $(P<0.01)$ during ripening (Table 2). The $317 \mathrm{HP}$ cheeses had the highest level of TCA-SN until $30 \mathrm{~d}$ of ripening; thereafter, this fraction was found at the highest level in 763SK11 cheeses. Differences in the level of TCA-SN between the cheeses were significant $(P<0.05)$ and as ripening advanced, these differences became greater. The observed differences in the level of TCA-SN in the $763 \mathrm{SK} 11$ and 317HP cheeses may be attributed to different proteolytic systems of the starters used (Law et al., 1992). A limited production of TCA-SN in the SF cheeses compared with the starter-ripened cheeses was evident during ripening, demonstrating the importance of starter lactococci in the formation of low molecular weight peptides and amino acids in cheese (O'Keeffe et al., 1976; Visser, 1977b; Rank et al., 1985).

PTA-SN. The formation of PTA-SN in the cheeses showed a similar trend to TCA-SN (Table 2). The level of amino acids in cheeses during ripening confirmed the results obtained from PTA-SN fraction as reported by Kawabata et al. (1997). Significant differences were found between the cheeses; that is, the formation of PTA-SN was lowest in SF cheese, and was highest in the 763SK11 cheeses during ripening, except at d 15 (Table 2). Visser (1977b) and Carmona et al. (1999) obtained similar results for starter-free cheeses; they noted that PTA-SN was formed at a very low level in these cheeses during ripening. The PTA-SN in the 763SK11 cheeses increased steadily during ripening and reached $3.2 \%$. Use of starter bacteria in cheese manufacture resulted in the accumulation of free amino 
Table 2. Soluble nitrogen fractions in Turkish White-brined cheeses.

\begin{tabular}{|c|c|c|c|c|}
\hline & \multirow{2}{*}{$\begin{array}{l}\text { Age of } \\
\text { cheese, } d\end{array}$} & \multicolumn{3}{|c|}{ Cheese $^{1}$} \\
\hline & & $\mathrm{SF}$ & 763SK11 & $317 \mathrm{HP}$ \\
\hline \multirow[t]{5}{*}{ Total N, \% } & 1 & $2.00 \pm 0.00^{\mathrm{a}}$ & $2.71 \pm 0.13^{b}$ & $2.66 \pm 0.07^{\mathrm{b}}$ \\
\hline & 15 & $2.01 \pm 0.10^{\mathrm{a}}$ & $2.71 \pm 0.05^{b}$ & $2.62 \pm 0.07^{b}$ \\
\hline & 30 & $2.03 \pm 0.07^{\mathrm{a}}$ & $2.70 \pm 0.09^{b}$ & $2.57 \pm 0.10^{\mathrm{b}}$ \\
\hline & 60 & $2.02 \pm 0.05^{\mathrm{a}}$ & $2.52 \pm 0.06^{\mathrm{b}}$ & $2.48 \pm 0.13^{\mathrm{b}}$ \\
\hline & 90 & $2.03 \pm 0.13^{\mathrm{a}}$ & $2.37 \pm 0.03^{\mathrm{ab}}$ & $2.52 \pm 0.02^{\mathrm{b}}$ \\
\hline \multirow{6}{*}{$\begin{array}{l}\text { Water-soluble N, \% } \\
\text { of total N }\end{array}$} & & & & \\
\hline & 1 & $6.31 \pm 0.43^{\mathrm{a}}$ & $7.88 \pm 0.33^{\mathrm{b}}$ & $9.80 \pm 0.49^{c}$ \\
\hline & 15 & $8.31 \pm 0.11^{\mathrm{a}}$ & $10.46 \pm 0.52^{\mathrm{b}}$ & $11.30 \pm 0.50^{\mathrm{b}}$ \\
\hline & 30 & $13.15 \pm 0.74^{\mathrm{a}}$ & $10.56 \pm 1.13^{\mathrm{b}}$ & $12.87 \pm 0.59^{\mathrm{a}}$ \\
\hline & 60 & $14.61 \pm 0.66^{\mathrm{a}}$ & $13.80 \pm 0.82^{\mathrm{a}}$ & $14.78 \pm 0.33^{\mathrm{a}}$ \\
\hline & 90 & $23.68 \pm 0.74^{\mathrm{a}}$ & $20.85 \pm 0.72^{\mathrm{b}}$ & $19.69 \pm 2.05^{\mathrm{b}}$ \\
\hline \multicolumn{5}{|l|}{$12 \%$ TCA-soluble } \\
\hline \multirow[t]{5}{*}{$\mathrm{N}, \%$ of total $\mathrm{N}$} & 1 & $1.46 \pm 0.16^{\mathrm{a}}$ & $2.97 \pm 0.45^{\mathrm{b}}$ & $3.30 \pm 0.01^{b}$ \\
\hline & 15 & $2.58 \pm 0.30^{\mathrm{a}}$ & $3.12 \pm 0.25^{\mathrm{ab}}$ & $4.17 \pm 0.29^{b}$ \\
\hline & 30 & $4.58 \pm 0.42^{\mathrm{a}}$ & $5.90 \pm 0.44^{\mathrm{b}}$ & $5.95 \pm 0.38^{\mathrm{b}}$ \\
\hline & 60 & $5.83 \pm 0.82^{\mathrm{a}}$ & $8.99 \pm 1.09^{\mathrm{ab}}$ & $7.76 \pm 0.07^{\mathrm{b}}$ \\
\hline & 90 & $7.56 \pm 0.51^{\mathrm{a}}$ & $13.46 \pm 0.80^{\mathrm{b}}$ & $10.69 \pm 0.41^{\mathrm{c}}$ \\
\hline \multirow{6}{*}{$\begin{array}{l}5 \% \text { phosphotungstic } \\
\text { acid-soluble N, \% of } \\
\text { total N }\end{array}$} & & & & \\
\hline & 1 & $0.51 \pm 0.05^{\mathrm{a}}$ & $0.84 \pm 0.07^{\mathrm{b}}$ & $0.83 \pm 0.03^{b}$ \\
\hline & 15 & $0.57 \pm 0.11^{\mathrm{a}}$ & $0.75 \pm 0.03^{\mathrm{ab}}$ & $0.90 \pm 0.04^{\mathrm{b}}$ \\
\hline & 30 & $0.80 \pm 0.12^{\mathrm{a}}$ & $1.37 \pm 0.18^{\mathrm{b}}$ & $0.98 \pm 0.14^{\mathrm{ab}}$ \\
\hline & 60 & $0.98 \pm 0.20^{\mathrm{a}}$ & $2.01 \pm 0.40^{\mathrm{b}}$ & $1.63 \pm 0.20^{\mathrm{ab}}$ \\
\hline & 90 & $1.59 \pm 0.27^{\mathrm{a}}$ & $3.22 \pm 0.48^{\mathrm{b}}$ & $2.12 \pm 0.21^{\mathrm{c}}$ \\
\hline
\end{tabular}

a,b,c Means in the same row having different letters are significantly different $(P<0.05)$.

${ }^{1}$ Cheeses: $\mathrm{SF}=$ starter free; 763SK11 = L. lactis ssp. lactis NCDO763 plus L. lactis ssp. cremoris SK11; $317 \mathrm{HP}=$ L. lactis ssp. lactis UC317 plus L. lactis ssp. cremoris HP.

acids, and as ripening proceeded, this difference became more evident, in agreement with the reports of several researchers, including Visser (1977b), Crow et al. (1993), Lane and Fox (1997), and Carmona et al. (1999).

\section{Total FAA}

The concentrations of total FAA in cheeses, as measured by the Cd-ninhydrin method, increased (Figure 3) gradually until $60 \mathrm{~d}$, and then sharply at $90 \mathrm{~d}$ of ripening. The 763SK11 and 317HP cheeses contained significantly higher concentrations of FAA than did the SF cheeses during ripening. As expected based on the results for PTA-SN, a greater increase in the level of FAA was observed in 763 SK11 cheese than in $317 \mathrm{HP}$ cheese during ripening, except at $d 1$. There was a 2 fold difference in the level of FAA between cheeses made with starter (763SK11 or 317HP) and the SF cheeses; however, at $90 \mathrm{~d}$, the level of FAA in SF cheeses increased sharply and was close to that of the $317 \mathrm{HP}$ cheese. Increased levels of FAA in the SF cheeses may be attributed to the contribution of nonstarter lactic acid bacteria to the accumulation of amino acids toward the end of ripening (Lane and Fox, 1996).

\section{Individual FAA}

Free AA are released by the action of lactococcal peptidases on small- and medium-sized peptides and con- tribute directly to cheeses flavor or act as precursors for flavor compounds (McSweeney and Sousa, 2000). The extent of proteolysis in the cheeses (expressed as $\mathrm{mg} / 100 \mathrm{~g}$ ) was also monitored by determining the levels of individual FAA at d 60. As shown in Figure 4, amino acid profiles of the cheeses reflected both the use of a

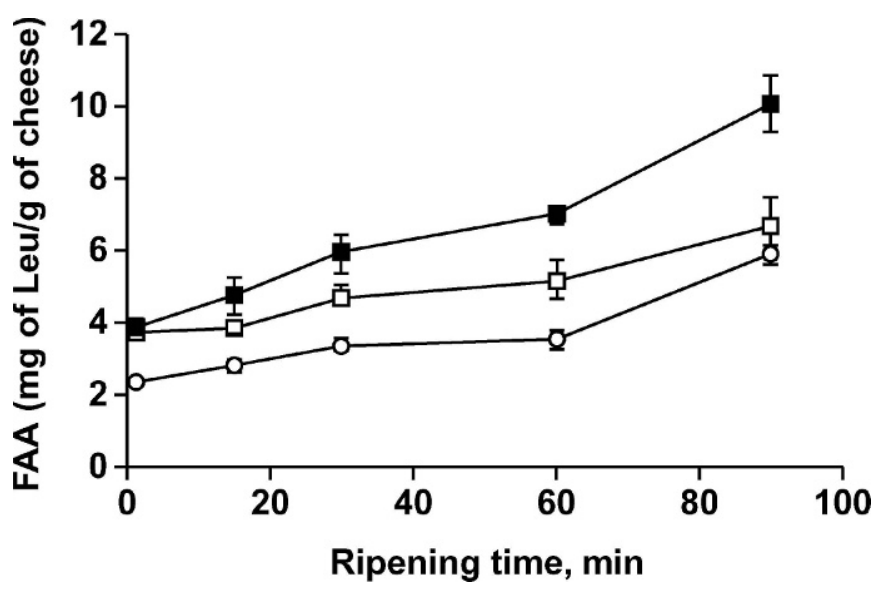

Figure 3. Formation of total free amino acids during ripening of Turkish white-brined cheeses made with starter culture systems 317HP (ם), 763SK11 $(\square)$, and SF $(\bigcirc)$. Cheeses: SF = starter free; 763 SK11 = L. lactis ssp. lactis NCDO763 plus L. lactis ssp. cremoris SK11; 317HP = L. lactis ssp. lactis UC317 plus L. lactis ssp. cremoris HP. 


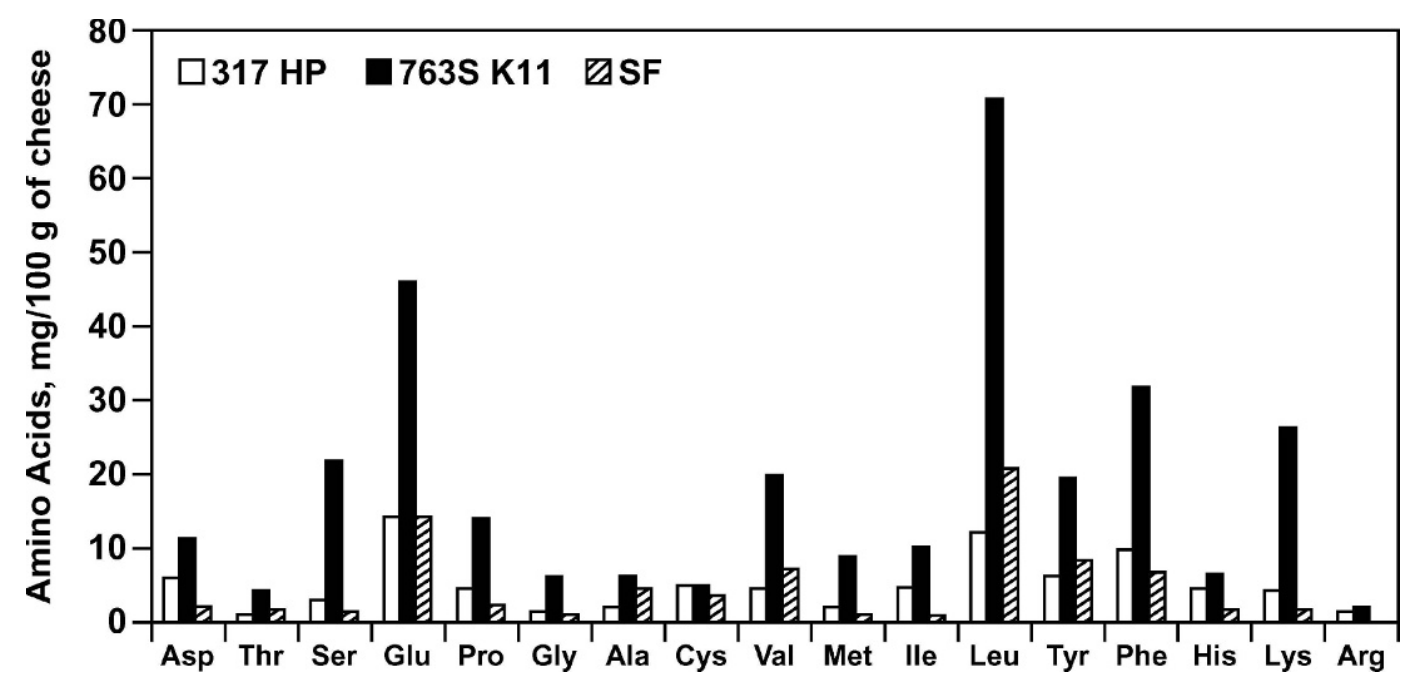

Figure 4. Individual free amino acid concentrations at $60 \mathrm{~d}$ in Turkish white-brined cheeses made with starter culture systems $317 \mathrm{HP}$

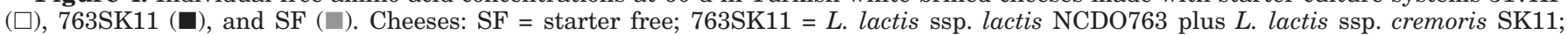
$317 \mathrm{HP}=$ L. lactis ssp. lactis UC317 plus L. lactis ssp. cremoris HP.

starter culture and the strain of starter; however, Leu, Glu, Phe, Lys, and Val were the principal amino acids in all cheeses. These FAA were also dominant in $60-\mathrm{d}-$ old Turkish White-brined cheeses as reported by other workers (Ucuncu, 1981; Hayaloglu et al., 2004). Higher concentrations of Ala, Val, Leu, and Tyr were found in $\mathrm{SF}$ cheeses than in $317 \mathrm{HP}$ cheeses, whereas 763SK11 cheeses had the highest concentrations of all FAA (Figure 3). These results highlight the important contribution of nonstarter lactic acid bacteria to the production of FAA in the cheese. This conclusion agrees with those reported by other workers (McSweeney et al., 1993; Fenelon et al., 1999; Ardo et al., 2002). In general, the concentrations of FAA in the experimental cheeses were in order 763SK11 $>>317 \mathrm{HP}>\mathrm{SF}$; and this correlated well with the concentration of total FAA determined by the Cd-ninhydrin method, as described above.

\section{Urea-PAGE Patterns}

Urea-PAGE electrophoretograms of the $\mathrm{pH}$ 4.6-insoluble fraction of the cheeses during ripening are shown in Figure 5. At the beginning of ripening period, no differences were seen between electrophoretograms of the cheeses (Table 3). As ripening progressed, hydrolysis of the caseins accelerated and $\alpha_{\mathrm{s} 1}$-casein was extensively degraded, especially after $30 \mathrm{~d}$. At $30 \mathrm{~d}$ of ripening, the residual $\alpha_{\mathrm{S} 1}$-casein in cheeses $\mathrm{SF}$, 763SK11, and $317 \mathrm{HP}$ was 76,59 , and $78 \%$ (as $\%$ of the level at $\mathrm{d} 1$ ), respectively. At the end of ripening, the respective values were 39,28 , and $50 \%$. The highest and lowest levels of $\alpha_{\mathrm{s} 1}$-casein degradation were found in the 763SK11 and 317HP cheeses, respectively (Table 3).
Two bands with faster electrophoretic mobility than $\alpha_{\mathrm{s} 1}$-casein (f24-199) appeared in the electrophoretograms of the SF cheeses after $30 \mathrm{~d}$ of ripening (Figure 5 ). The region of $\alpha_{\mathrm{s} 1}$-casein degradation products on the gel was different in 763SK11 and 317HP cheeses after $60 \mathrm{~d}$ of ripening, perhaps due to differences in the specificity of cell envelope-associated proteinase. For example, L. lactis ssp. lactis NCDO763 and cremoris SK11 have a $\mathrm{P}_{\mathrm{III}}$-type enzyme (Visser, 1993), whereas L. lactis ssp. lactis UC317 and cremoris $\mathrm{HP}$ have $\mathrm{P}_{\mathrm{I} / \mathrm{III}-}$ and $\mathrm{P}_{\mathrm{I}^{-}}$ type enzymes, respectively (Law et al., 1992; Tan et al., 1993). $\beta$-Casein was degraded slowly during ripening; and it is resistant to hydrolysis as in other brine-ripened cheeses (Alichanidis et al., 1984; Saldamli and Kaytanli, 1998; Katsiari et al., 2000; Romeih et al., 2002). Some weak bands appeared in the $\gamma$-casein region in all cheeses; however, compared with the cheese made with a starter, the SF cheeses had a slightly higher concentration of $\gamma$-caseins, reflecting higher plasmin activity due to higher $\mathrm{pH}$ in these cheeses. In whitebrined cheeses, the principal proteolytic agents are the residual coagulant and enzymes from starters or the indigenous microflora. Extensive plasmin activity is not expected in this type of cheese due to its acidity and salt content, both of which are unfavorable for plasmin action (Michaelidou et al., 1998; Kandarikis et al., 2001). Differences between the electrophoretic patterns of the $\mathrm{pH}$ 4.6-insoluble fractions of the cheeses were monitored using PCA and HCA, and the results are shown in Figure 6. Component PC1 separated the cheeses based on their age, and PC2 separated the cheese based on the treatments; they accounted for 82.5 and $10.7 \%$ of variation, respectively. Cheeses with 

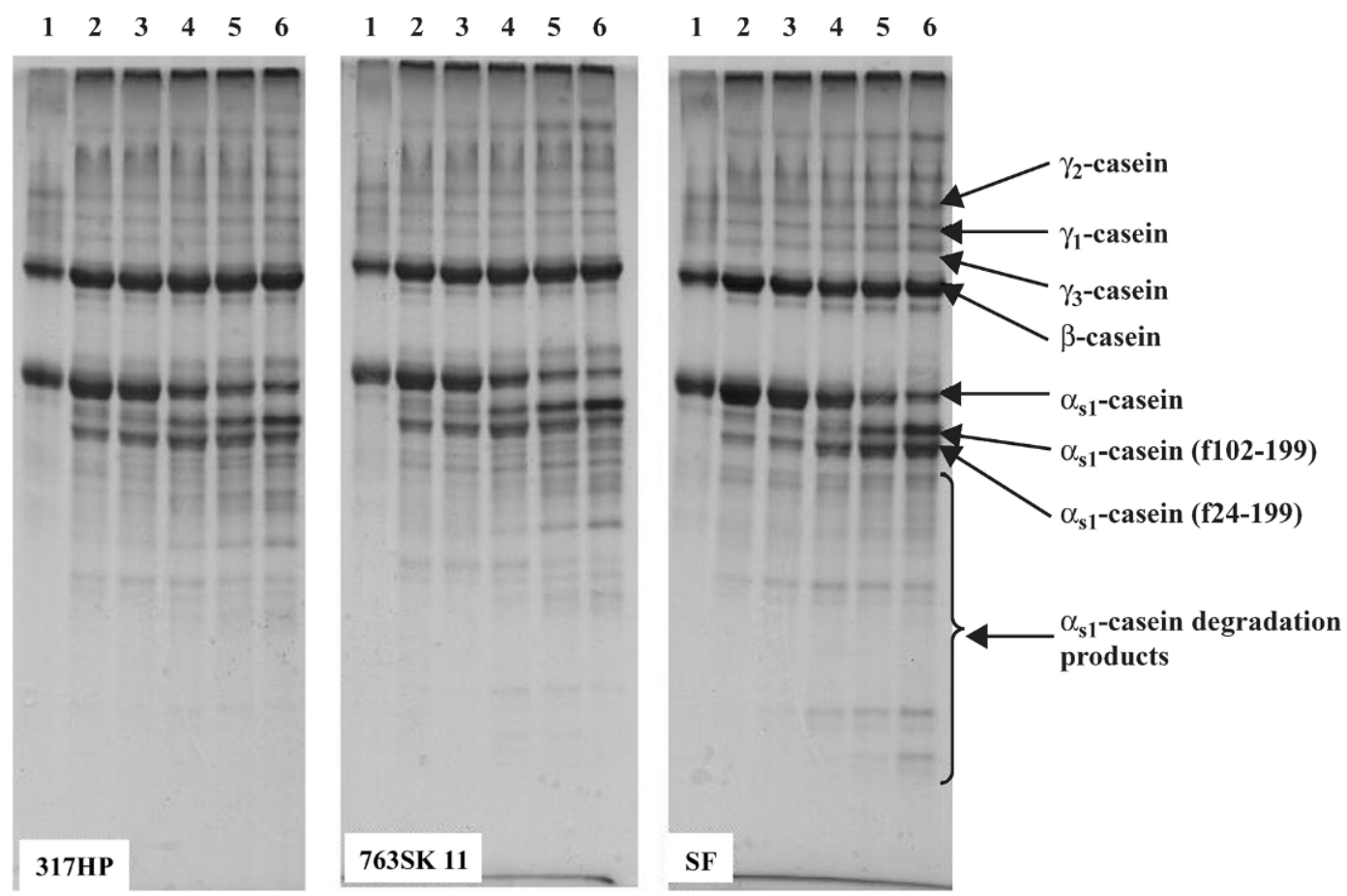

Figure 5. Urea-PAGE electrophoretograms of the $\mathrm{pH}$ 4.6-insoluble fractions of Turkish white-brined cheeses made with starter culture systems 317HP, 763SK11, and SF. Lane 1 = sodium-caseinate; lanes 2 to 6 = cheeses after 1, 15, 30, 60, and $90 \mathrm{~d}$ of ripening, respectively. Cheeses: $\mathrm{SF}=$ starter free; 763SK11 = L. lactis ssp. lactis NCDO763 plus L. lactis ssp. cremoris SK11; 317HP = L. lactis ssp. lactis UC317 plus L. lactis ssp. cremoris HP.

shortest ripening times (1- and 15-d-old cheeses) were located separately, and other groups for 30,60 , or 90 $\mathrm{d}$ of ripening for each cheeses separated as marked on Figure 6.

\section{RP-HPLC Peptide Profiles}

70\% (vol/vol) ethanol-soluble fractions. Figure 7 shows the RP-HPLC peptide profiles of the ethanolsoluble (EtOH-s) fractions of the $\mathrm{pH} 4.6$-soluble fractions of the 60- and 90-d-old cheeses. Chromatograms of the $70 \% \mathrm{EtOH}-\mathrm{s}$ fractions were similar to those of $\mathrm{pH} 4.6$-soluble fractions of the cheeses. The 763SK11 cheeses showed higher concentrations of peptides eluting with retention times of 9 and 13 min than the other cheeses. These peaks were probably due to amino acids or low-molecular weight peptides produced by the action of starter strains (NCDO763 or SK11 strains). In our previous study (Hayaloglu et al., 2004), we observed that the use of NCDO763 or SK11 in Turkish Whitebrined cheese gave peaks with corresponding retention times. The peaks eluting with retention times of 26 or 33 min were common in the cheeses; however, their concentrations were different. Higher concentrations of peptides with retention times of 40 to 60 min were present in the EtOH-s fractions of SF cheeses than the

Table 3. Mean values of residual $\beta$-casein and $\alpha_{\mathrm{s} 1}$-casein in Turkish White-brined cheeses. ${ }^{1}$

\begin{tabular}{lccccccc}
\hline \multirow{2}{*}{$\begin{array}{l}\text { Age of } \\
\text { cheese, } d\end{array}$} & \multicolumn{3}{c}{ Residual $\beta$-casein, $\%$} & & \multicolumn{3}{c}{ Residual $\alpha_{\text {s1 }}$-casein, \% } \\
\cline { 2 - 4 } \cline { 6 - 8 } & SF & 763 SK11 & $317 \mathrm{HP}$ & & SF & 763 SK11 & $317 \mathrm{HP}$ \\
\hline 1 & 100 & 100 & 100 & & 100 & 100 & 100 \\
15 & $93.8^{\mathrm{a}}$ & $96.9^{\mathrm{b}}$ & $95.1^{\mathrm{b}}$ & $86.3^{\mathrm{a}}$ & $81.2^{\mathrm{b}}$ & $86.8^{\mathrm{a}}$ \\
30 & $91.0^{\mathrm{a}}$ & $94.3^{\mathrm{b}}$ & $93.9^{\mathrm{b}}$ & & $76.3^{\mathrm{a}}$ & $58.7^{\mathrm{b}}$ & $78.1^{\mathrm{a}}$ \\
60 & $89.6^{\mathrm{a}}$ & $88.0^{\mathrm{a}}$ & $83.5^{\mathrm{b}}$ & & $62.0^{\mathrm{a}}$ & $43.6^{\mathrm{b}}$ & $59.3^{\mathrm{c}}$ \\
90 & $84.3^{\mathrm{a}}$ & $84.9^{\mathrm{a}}$ & $80.1^{\mathrm{b}}$ & & $38.6^{\mathrm{a}}$ & $27.9^{\mathrm{b}}$ & $50.3^{\mathrm{c}}$ \\
\hline
\end{tabular}

${ }^{\mathrm{a}, \mathrm{b}, \mathrm{c}}$ Means in the same row having different letters are significantly different $(P<0.05)$.

${ }^{1}$ Cheeses: $\mathrm{SF}=$ starter free; 763SK11 = L. lactis ssp. lactis NCDO763 plus L. lactis ssp. cremoris SK11; $317 \mathrm{HP}=$ L. lactis ssp. lactis UC317 plus L. lactis ssp. cremoris HP. 

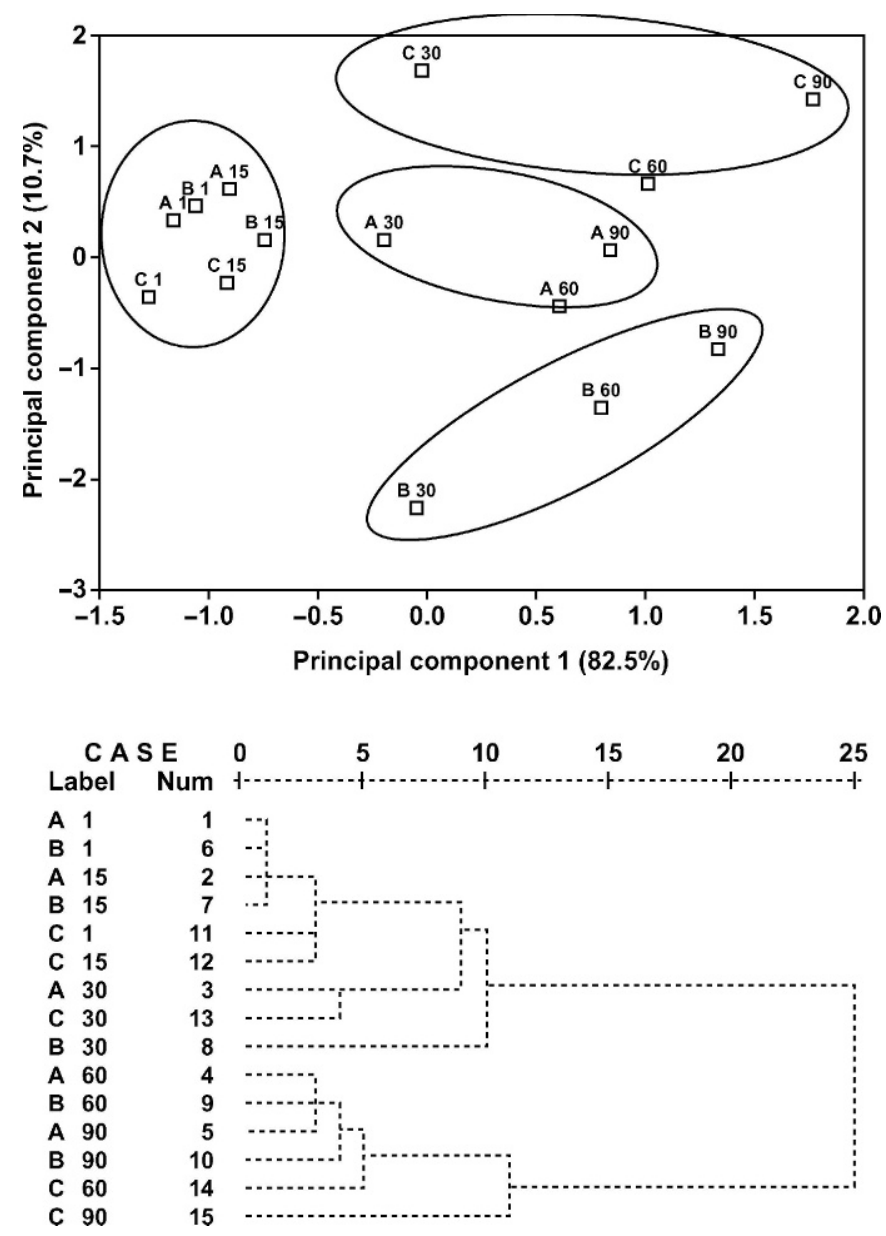

Figure 6. Principal component (top) and hierarchical cluster (bottom) analyses of densitometric data from urea-PAGE of the $\mathrm{pH} 4.6$ insoluble fractions of the cheeses made with starter culture systems SF (A), 763SK11 (B), and 317HP (C). Cheeses: SF = starter free; 763 SK11 $=$ L. lactis ssp. lactis NCDO763 plus L. lactis ssp. cremoris $\mathrm{SK} 11 ; 317 \mathrm{HP}=$ L. lactis ssp. lactis UC317 plus L. lactis ssp. cremoris $\mathrm{HP}$.

cheeses made with a starter culture. These differences were confirmed by the use of multivariate statistical analyses; PCA or HCA on chromatographic data distributed the cheeses into 3 groups as shown in Figure 8. The 763SK11 cheeses, located on the positive side of PC1, had higher concentrations for peaks eluting with retention times of 9,13 , and 27 min (they could be considered hydrophilic peptides) than the other cheeses. Similar results were reported by Lane and Fox (1997), Shakeel-Ur-Rehman et al. (1999), and Poveda et al. (2003), who reported that the starter enzymes had a significant effect on the formation/breakdown of peptides soluble in $70 \%$ ethanol.

$70 \%$ (vol/vol) ethanol-insoluble fractions. The RP-HPLC peptide profiles of the EtOH-i fractions of the 60- or 90-d-old cheeses are shown in Figure 9. Quali-

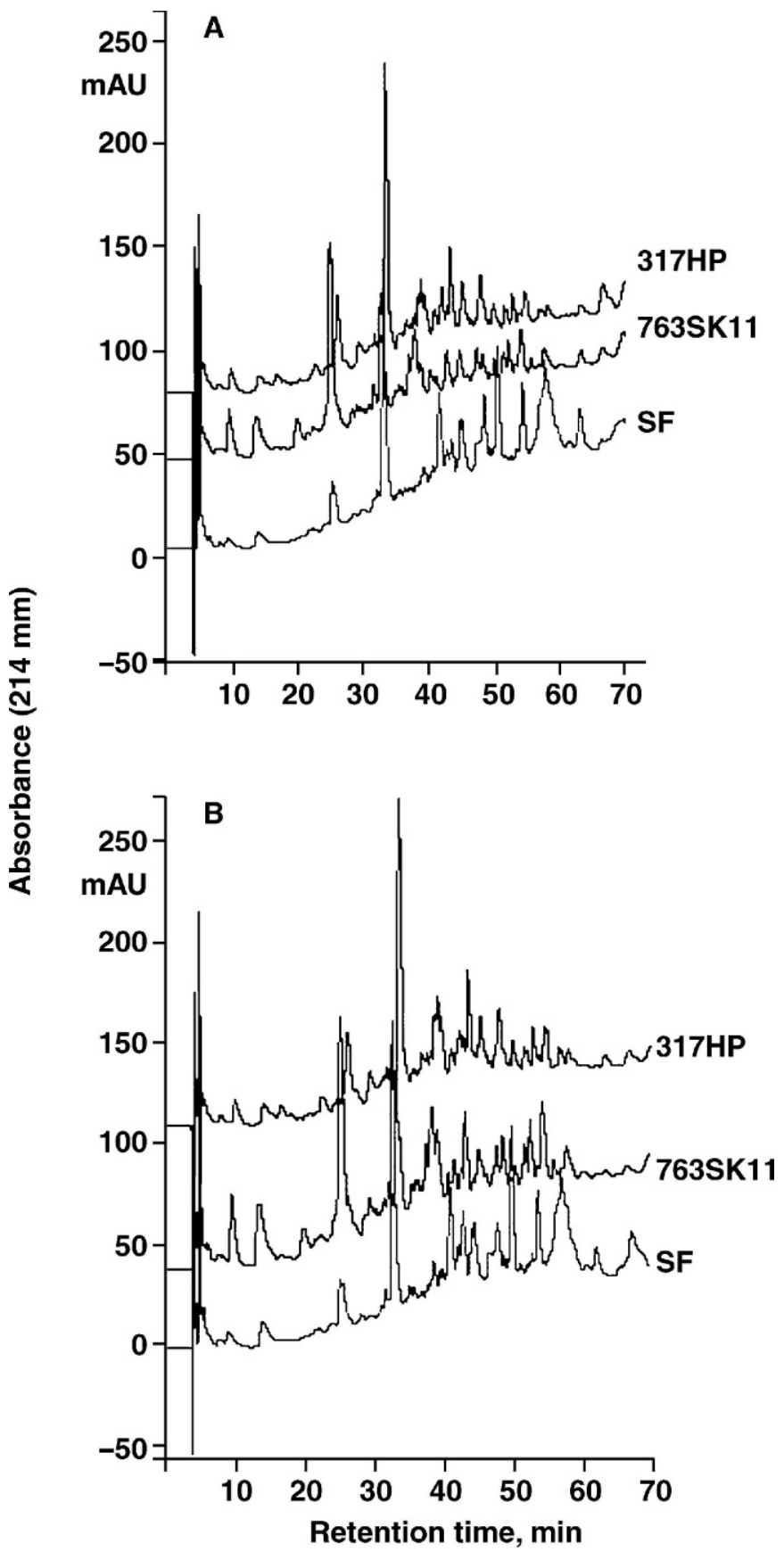

Figure 7. Reversed phase-HPLC peptide profiles of the 70\% ethanol-soluble fractions from Turkish White-brined cheeses made with starter culture systems 317HP, 763SK11, and SF at 60 (A) and 90 (B) d of ripening. Cheeses: $\mathrm{SF}=$ starter free; $763 \mathrm{SK} 11=$ L. lactis $\mathrm{ssp}$. lactis NCDO763 plus L. lactis $\mathrm{ssp}$. cremoris $\mathrm{SK} 11 ; 317 \mathrm{HP}=$ L. lactis ssp. lactis UC317 plus L. lactis ssp. cremoris HP.

tative and quantitative differences were observed in the chromatograms of the cheeses, particularly in the hydrophobic region (from 45 to $60 \mathrm{~min}$ ). No major differences were observed between the peptide profiles of EtOH-i fractions from 763 SK11 or $317 \mathrm{HP}$ cheeses at 

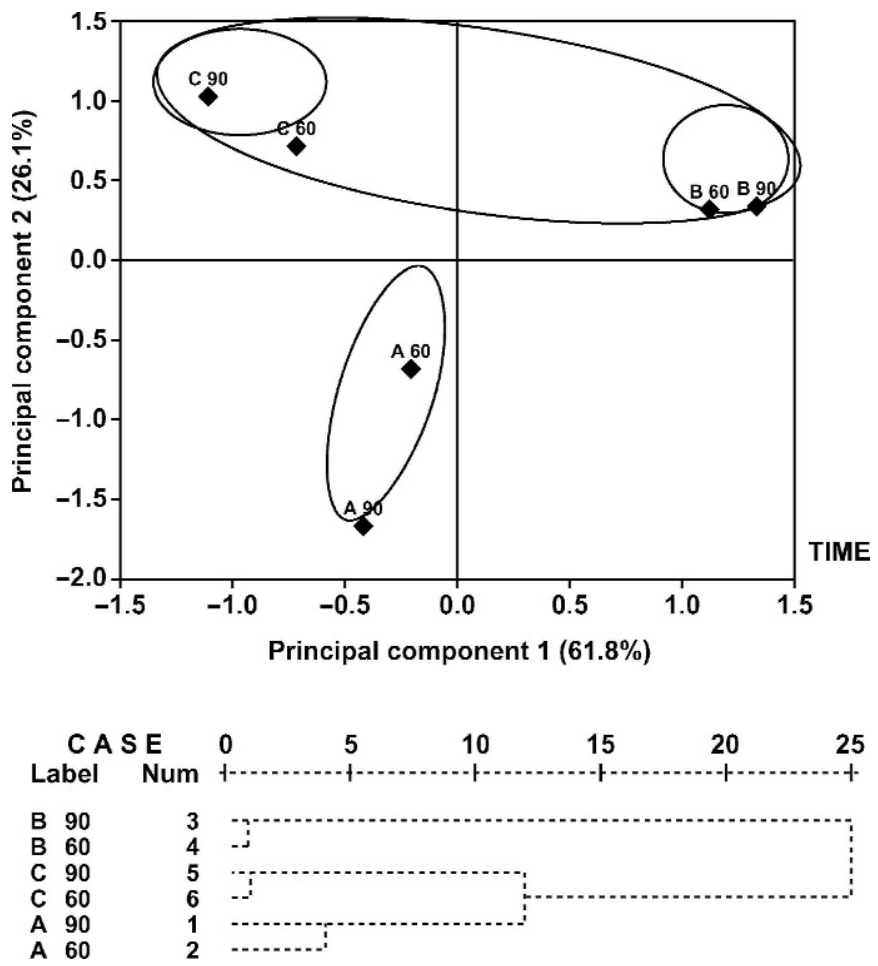

Figure 8. Principal component (top) and hierarchical cluster (bottom) analyses of chromatographic data from RP-HPLC profiles of the $70 \%$ ethanol-soluble fractions of the cheeses made with starter culture systems SF (A), 763SK11 (B), and 317HP (C). Cheeses: SF = starter free; 763 SK $11=$ L. lactis ssp. lactis NCDO763 plus L. lactis ssp. cremoris $\mathrm{SK} 11 ; 317 \mathrm{HP}=$ L. lactis $\mathrm{ssp}$. lactis $\mathrm{UC} 317$ plus L. lactis $\mathrm{ssp}$. cremoris HP.

early retention times ( 5 to $20 \mathrm{~min}$ ); it can be concluded that hydrophilic peptides were soluble in $70 \%$ ethanol, whereas the hydrophobic peptides were mainly in the EtOH-i fraction. Chromatograms of the EtOH-i fractions showed that some of the peptides present at higher concentrations were eluted in the hydrophobic region (40 to $60 \mathrm{~min}$ ) in SF cheeses. Urea-PAGE electrophoretograms of the $\mathrm{EtOH}-\mathrm{i}$ fractions of the cheeses showed that the $763 \mathrm{SK} 11$ or $317 \mathrm{HP}$ cheeses exhibited similar patterns on the gels, but SF cheeses showed clear differences from the others as shown in Figure 10. Comparing the urea-PAGE patterns of the EtOH-i fractions of the cheeses, we suggest that the starter enzymes played a significant role in the breakdown of these fractions during ripening (Visser, 1977a; Lau et al., 1991; Tan et al., 1993; Lee et al., 1996; Gomez et al., 1997; Rampilli et al., 1997). Principal component analysis and HCA obtained from the RP-HPLC of the EtOH-i fractions grouped the cheeses. Cheeses were divided into 2 groups; one including the $763 \mathrm{SK} 11$ and $317 \mathrm{HP}$ cheeses at 60 and $90 \mathrm{~d}$ of ripening period, whereas the other included SF cheeses (Figure 11). However, differences were observed between the SF cheeses at 60 and $90 \mathrm{~d}$

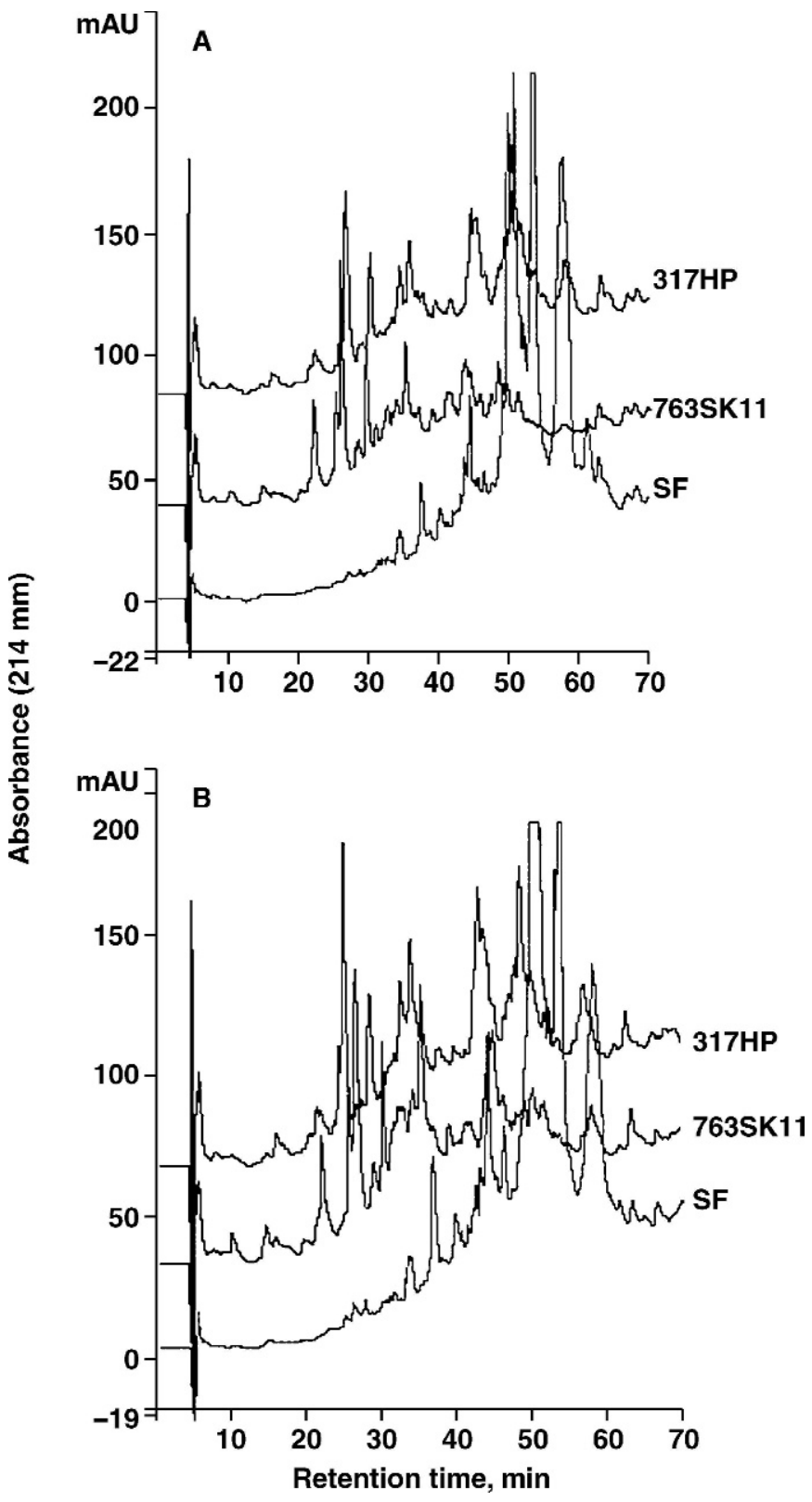

Figure 9. Reversed phase-HPLC peptide profiles of the $70 \%$ ethanol-insoluble fractions from Turkish White-brined cheeses made with starter culture systems $317 \mathrm{HP}, 763 \mathrm{SK} 11$, and SF at 60 (A) or 90 (B) $\mathrm{d}$ of ripening. Cheeses: $\mathrm{SF}=$ starter free; $763 \mathrm{SK} 11=L$. lactis ssp. lactis NCDO763 plus L. lactis ssp. cremoris SK11; 317HP = L. lactis ssp. lactis UC317 plus L. lactis ssp. cremoris HP.

of ripening period; these were located on the opposite side of $\mathrm{PC} 2$.

\section{Sensory Evaluation}

The mean sensory scores of the experimental cheeses are shown in Table 4. A salty taste was usually pronounced for all samples during maturation, probably 


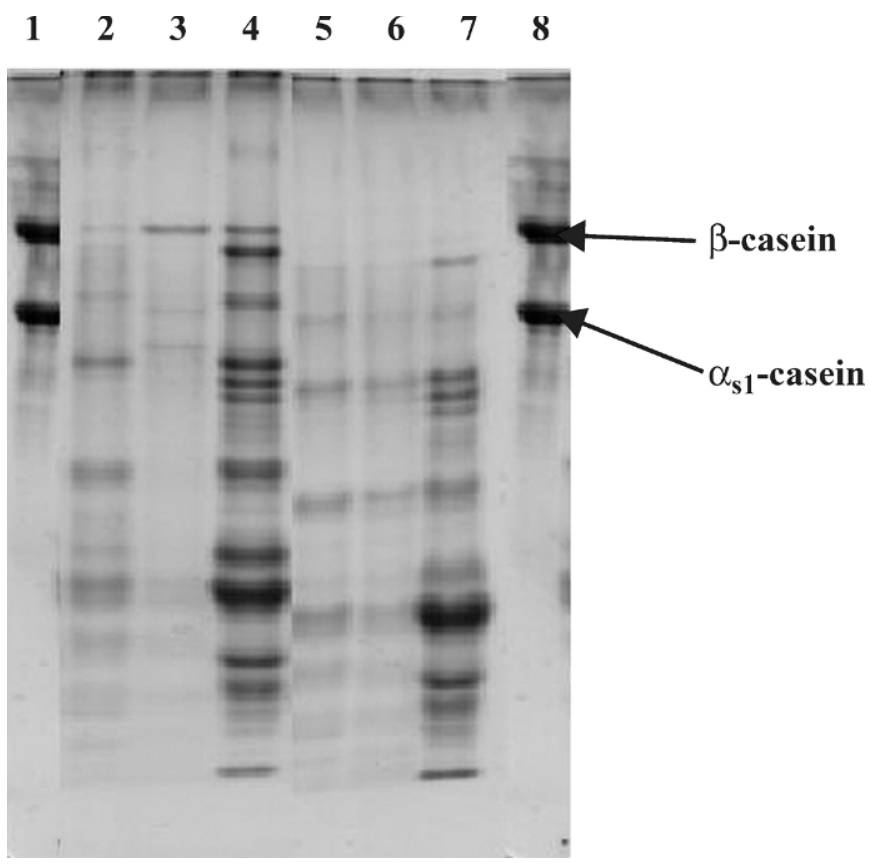

Figure 10. Urea-PAGE electrophoretograms of the 70\% ethanolinsoluble fractions of Turkish white-brined cheeses made with starter culture systems $317 \mathrm{HP}, 763 \mathrm{SK} 11$, and SF. Lanes 1 and $8=$ sodiumcaseinate; lanes 2 and $5=\mathrm{SF}$ cheese, lanes 3 and $6=763 \mathrm{SK} 11$ cheese, and lanes 4 and $7=317 \mathrm{HP}$ cheese after 60 or $90 \mathrm{~d}$ of ripening, respectively. Cheeses: $\mathrm{SF}=$ starter free; 763SK11 $=$ L. lactis ssp. lactis NCDO763 plus L. lactis ssp. cremoris SK11; 317HP = L. lactis ssp. lactis UC317 plus L. lactis ssp. cremoris HP.

due to the salty and acidic nature of this type of cheese. No significant differences were noted between the 763SK11 and 317HP cheeses during maturation in terms of all sensory scores. However, the graders reported that 763SK11 cheeses had more flavor or flavor intensity after $15 \mathrm{~d}$ of ripening and that their superiority increased as the cheese aged. Although L. lactis ssp. cremoris HP, which was present in the $317 \mathrm{HP}$ cheese, produces bitter peptides (Law et al., 1992), no bitter flavor was detected in the $317 \mathrm{HP}$ cheeses during aging. The SF cheeses received considerably lower values for all sensory scores than the other cheeses at all ripening periods. Firstly, their appearance and texture were not typical for white-brined cheeses; the SF cheeses had a few holes inside the molds due to presence of gasproducing bacteria (due to lack of a dominant starter). In addition, the SF cheeses received the lowest scores for flavor and odor $(P<0.01)$, indicating that the use of a starter culture in cheese manufacture resulted in some improvements in flavor and aroma development. The lower level of flavor intensity in the SF cheeses may be correlated with lower levels of $\mathrm{N}$ fractions and FAA of the cheese than in the other cheeses as reported by several researchers (Urbach 1993; Tzanetakis et al.,
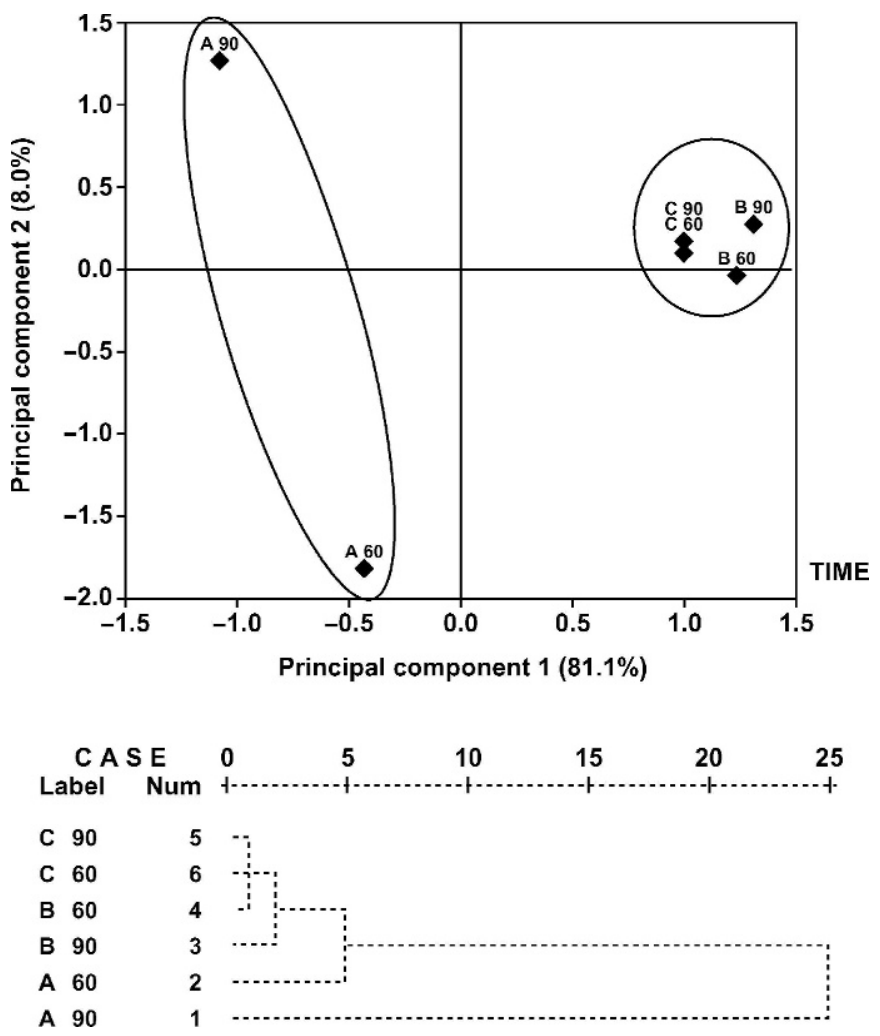

Figure 11. Principal component (top) and hierarchical cluster (bottom) analyses of chromatographic data from RP-HPLC profiles of the $70 \%$ ethanol-insoluble fractions of the cheeses made with starter culture systems SF (A), 763SK11 (B), and 317HP (C). Cheeses: SF = starter free; 763 SK $11=L$. lactis ssp. lactis NCDO763 plus L. lactis ssp. cremoris $\mathrm{SK} 11 ; 317 \mathrm{HP}=$ L. lactis ssp. lactis UC317 plus L. lactis ssp. cremoris HP.

1995; Urbach, 1997; Broome and Limsowtin, 1998; Madkor et al., 2000). A soft texture was noted in all cheeses toward the end of ripening; this may be linked to the degradation of $\alpha_{\mathrm{s} 1}$-casein (Lawrence et al., 1987; Fenelon et al., 1999). Although the 763SK11 and 317HP cheeses received similar sensory scores, the graders differentiated the 2 cheeses and awarded the 763SK11 cheese the best final score for both flavor and odor. The graders' preference for the cheeses was in the order $763 \mathrm{SK} 11>317 \mathrm{HP}>>\mathrm{SF}$.

\section{CONCLUSIONS}

The results clearly show that the use of a starter culture in the manufacture of Turkish White-brined cheese influenced the chemistry, biochemistry, and sensory characteristics of the cheeses during ripening period. However, the different starters used did not significantly influence the gross composition or the sensory attributes. Cheeses made with NCDO763 and SK11 in combination exhibited a significantly higher extent of 
Table 4. Sensory scores of Turkish White-brined cheeses.

\begin{tabular}{|c|c|c|c|c|}
\hline & \multirow{2}{*}{$\begin{array}{l}\text { Age of } \\
\text { cheese, } d\end{array}$} & \multicolumn{3}{|c|}{ Cheese $^{1}$} \\
\hline & & SF & 763SK11 & $317 \mathrm{HP}$ \\
\hline Color and appearance & $\begin{array}{r}1 \\
15 \\
30 \\
60 \\
90\end{array}$ & $\begin{array}{l}13.80 \pm 1.34^{\mathrm{a}} \\
11.00 \pm 0.84^{\mathrm{a}} \\
12.07 \pm 1.10^{\mathrm{a}} \\
10.60 \pm 1.03^{\mathrm{a}} \\
11.67 \pm 0.78^{\mathrm{a}}\end{array}$ & $\begin{array}{l}17.87 \pm 0.41^{b} \\
17.47 \pm 0.51^{b} \\
18.13 \pm 0.40^{b} \\
18.20 \pm 0.28^{b} \\
18.00 \pm 0.32^{b}\end{array}$ & $\begin{array}{l}18.53 \pm 0.46^{b} \\
18.20 \pm 0.43^{b} \\
17.93 \pm 0.23^{b} \\
18.87 \pm 0.35^{b} \\
18.20 \pm 0.40^{b}\end{array}$ \\
\hline Texture & $\begin{array}{r}1 \\
15 \\
30 \\
60 \\
90\end{array}$ & $\begin{array}{l}24.00 \pm 1.96^{\mathrm{a}} \\
19.60 \pm 1.88^{\mathrm{a}} \\
16.20 \pm 1.40^{\mathrm{a}} \\
11.87 \pm 1.09^{\mathrm{a}} \\
16.60 \pm 1.44^{\mathrm{a}}\end{array}$ & $\begin{array}{l}30.67 \pm 0.65^{b} \\
29.60 \pm 1.01^{b} \\
30.20 \pm 0.96^{b} \\
29.13 \pm 1.75^{b} \\
29.40 \pm 1.14^{b}\end{array}$ & $\begin{array}{l}30.60 \pm 0.79^{b} \\
29.40 \pm 0.94^{b} \\
30.87 \pm 0.67^{b} \\
30.80 \pm 1.16^{b} \\
30.00 \pm 1.01^{b}\end{array}$ \\
\hline Odor & $\begin{array}{r}1 \\
15 \\
30 \\
60 \\
90\end{array}$ & $\begin{array}{l}8.00 \pm 0.28^{\mathrm{a}} \\
7.80 \pm 0.43^{\mathrm{a}} \\
7.27 \pm 0.56^{\mathrm{a}} \\
7.20 \pm 0.79^{\mathrm{a}} \\
7.53 \pm 0.38^{\mathrm{a}}\end{array}$ & $\begin{array}{l}9.60 \pm 0.21^{b} \\
9.47 \pm 0.19^{b} \\
9.73 \pm 0.15^{b} \\
9.60 \pm 0.16^{b} \\
9.60 \pm 0.19^{b}\end{array}$ & $\begin{array}{l}9.20 \pm 0.28^{b} \\
9.53 \pm 0.19^{b} \\
9.47 \pm 0.19^{b} \\
9.67 \pm .13^{b} \\
9.40 \pm 0.24^{b}\end{array}$ \\
\hline Flavor & $\begin{array}{r}1 \\
15 \\
30 \\
60 \\
90\end{array}$ & $\begin{array}{l}21.87 \pm 0.79^{\mathrm{a}} \\
20.93 \pm 1.50^{\mathrm{a}} \\
19.53 \pm 1.66^{\mathrm{a}} \\
18.67 \pm 1.58^{\mathrm{a}} \\
18.00 \pm 1.60^{\mathrm{a}}\end{array}$ & $\begin{array}{l}30.27 \pm 0.52^{\mathrm{b}} \\
29.27 \pm 0.81^{\mathrm{b}} \\
31.53 \pm 0.73^{\mathrm{b}} \\
31.80 \pm 0.99^{\mathrm{b}} \\
32.27 \pm 0.56^{\mathrm{b}}\end{array}$ & $\begin{array}{l}29.07 \pm 0.88^{b} \\
31.33 \pm 0.84^{b} \\
32.07 \pm 0.51^{b} \\
32.47 \pm 0.32^{b} \\
31.40 \pm 0.88^{b}\end{array}$ \\
\hline Total score & $\begin{array}{r}1 \\
15 \\
30 \\
60 \\
90\end{array}$ & $\begin{array}{l}67.67 \pm 3.34^{\mathrm{a}} \\
59.33 \pm 3.45^{\mathrm{a}} \\
55.07 \pm 3.62^{\mathrm{a}} \\
48.33 \pm 2.96^{\mathrm{a}} \\
53.80 \pm 3.08^{\mathrm{a}}\end{array}$ & $\begin{array}{l}88.40 \pm 0.75^{b} \\
85.80 \pm 1.54^{b} \\
89.60 \pm 1.49^{b} \\
88.73 \pm 2.31^{b} \\
89.27 \pm 1.67^{b}\end{array}$ & $\begin{array}{l}87.40 \pm 1.72^{\mathrm{b}} \\
88.47 \pm 1.29^{\mathrm{b}} \mathrm{b} \\
90.33 \pm 1.23^{\mathrm{b}} \\
91.80 \pm 1.45^{\mathrm{b}} \\
89.00 \pm 1.82^{\mathrm{b}}\end{array}$ \\
\hline
\end{tabular}

${ }^{\mathrm{a}, \mathrm{b}}$ Means in the same row having different letters are significantly different $(P<0.05)$.

${ }^{1}$ Cheeses: $\mathrm{SF}=$ starter free; 763SK11 = L. lactis ssp. lactis NCDO763 plus L. lactis ssp. cremoris SK11; $317 \mathrm{HP}=$ L. lactis ssp. lactis UC317 plus L. lactis ssp. cremoris HP.

proteolysis (i.e., soluble $\mathrm{N}$ fractions, total and individual FAA contents, peptide profiles) and higher flavor intensity than the cheeses made with UC317 and HP in combination due to the different proteolytic enzyme systems of the strains used. In contrast, cheeses manufactured without a starter had lower concentrations of soluble N, total and individual FAA, and sensory scores. Considerable differences were found between the SF cheese and the starter cheeses (763SK11 or 317HP) during cheese making and aging. Results obtained demonstrated that the use of a starter is essential for cheese making.

In general, the urea-PAGE patterns and the RPHPLC peptide profiles of the cheeses showed slight differences between the samples in the early ripening times (until $15 \mathrm{~d}$ ); but the differences increased at the advanced stages of ripening. The highest concentrations of total or individual FAA were found in the 763 SK11 cheeses; Leu, Glu, Phe, Lys, and Val were the principal FAA in all cheeses. Principal component analysis or HCA of the data obtained from the ureaPAGE patterns and from the RP-HPLC peptide profiles of the cheeses classified the samples according to ripening time.

\section{ACKNOWLEDGMENT}

This research was funded in part by Scientific Research Project Units of Cukurova University (Adana, Turkey).

\section{REFERENCES}

Abd El-Salam, M. H., E. Alichanidis, and G. K. Zerfiridis. 1993. Domiati and Feta type cheeses. Pages 301-335 in Cheese: Chemistry, Physics and Microbiology. Vol. 2. P.F. Fox, ed. 2nd ed. Chapman and Hall, London, UK.

Alichanidis, E., E. M. Anifantakis, A. Polychroniadou, and M. Nanou. 1984. Suitability of some microbial coagulants for Feta cheese manufacture. J. Dairy Res. 51:141-147.

Andrews, A. T. 1983. Proteinases in normal bovine milk and their action on caseins. J. Dairy Res. 50:45-55.

AOAC. 1995. Official Methods of Analysis. Vol. II. 16th ed. Association of Official Analytical Chemists International, Arlington, VA.

Ardo, Y., and A. Polychroniadou. 1999. Laboratory Manual for Chemical Analysis of Cheese. COST 95, Luxembourg. Office for Official Publications of the European Communities, Luxembourg.

Ardo, Y., B. V. Thange, and J. S. Madsen. 2002. Dynamics of free amino acid composition in cheese ripening. Aust. J. Dairy Technol. 57:109-115.

Awad, S., Q. Q. Luthi-Peng, and Z. Puhan. 1999. Influence of coagulants and starter bacteria on proteolysis and sensory quality of Gouda type cheese from buffalo milk. Sci. Tecn. Latt. Cas. 50:405-430.

Bintis, T., and P. Papademas. 2002. Microbiological quality of whitebrined cheeses: A review. Int. J. Dairy Technol. 55:113-120. 
Blakesley, R. W., and J. A. Boezi. 1977. A new staining technique for proteins in polyacrylamide gels using Coomassie Brilliant Blue G250. Anal. Biochem. 82:580-581.

Bradley, R. L., E. Arnold, D. M. Barbano, R. G. Semerad, D. E. Smith, and B. K. Vines. 1993. Chemical and physical methods. Pages 433-531 in Standard Methods for the Examination of Dairy Products. 16th ed. R. T. Marshall, ed. American Public Health Association, Washington, DC.

Broome, M. C., and G. K. Y. Limsowtin. 1998. Starter peptidase activity in maturing cheese. Aust. J. Dairy Technol. 53:79-82.

Carmona, M. A., E. Sanjuan, R. Gomez, and J. Fernandez-Salguero. 1999. Effect of starter cultures on the physico-chemical and biochemical features in ewe cheese made with extracts from flowers of Cynara cardunculus L. J. Sci. Food Agric. 79:737-744.

Crow, V. L., T. Coolbear, R. Holland, G. G. Pritchard, and F. G. Martley. 1993. Starters as finishers: Starter properties relevant to cheese ripening. Int. Dairy J. 3:423-460.

El Soda, M., N. Farkye, J. C. Vuillemard, R. E. Simard, N. F. Olson, W. El Kholy, E. Dako, E. Medrano, M. Gaber, and L. Lim. 1995. Autolysis of lactic acid bacteria: Impact on flavour development in cheese. Pages 2205-2223 in Food Flavours: Generation, Analysis and Process Influence. G. Charalambous, ed. Elsevier Sciences B.V., Amsterdam, The Netherlands.

Fenelon, M. A., P. O'Connor, and T. P. Guinee. 2000. The effect of fat content on the microbiology and proteolysis in Cheddar cheese during ripening. J. Dairy Sci. 83:2173-2183.

Fenelon, M. A., M. P. Ryan, M. C. Rea, T. P. Guinee, R. P. Ross, C. Hill, and D. Harrington. 1999. Elevated temperature ripening of reduced fat Cheddar cheese made with or without lacticin 3147producing starter culture. J. Dairy Sci. 82:10-22.

Folkertsma, B., and P. F. Fox. 1992. Use of Cd-ninhydrin reagent to assess proteolysis in cheese during ripening. J. Dairy Res. 59:217-224.

Fox, P. F. 1989. Proteolysis during cheese manufacture and ripening. J. Dairy Sci. 72:1379-1400.

Fox, P. F., T. P. Guinee, T. M. Cogan, and P. L. H. McSweeney. 2000. Fundamentals of Cheese Science. Aspen Publishers, Inc., Gaithersberg, MD.

Fox, P. F., J. Law, P. L. H. McSweeney, and J. Wallace. 1993. Biochemistry of cheese ripening. Pages 389-438 in Cheese: Chemistry, Physics and Microbiology. Vol. 1. P. F. Fox, ed. 2nd ed. Chapman and Hall, London, UK.

Gomez, M. J., S. Garde, P. Gaya, M. Medina, and M. Nunez. 1997. Relationship between level of hydrophobic peptide and bitterness in cheese made from pasteurised and raw milk. J. Dairy Res. 64:289-297.

Hayaloglu, A. A., M. Guven, and P. F. Fox. 2002. Microbiological, biochemical and technological properties of Turkish White-brined cheese "Beyaz Peynir". Int. Dairy J. 12:635-648.

Hayaloglu, A. A., M. Guven, P. F. Fox, J. A. Hannon, and P. L. H. McSweeney. 2004. Proteolysis in Turkish White-brined cheese made with defined strains of Lactococcus. Int. Dairy J. 14:599_ 610.

International Dairy Federation. 1982. Determination of the total solid content (cheese and processed cheese). IDF Standard 4A. International Dairy Federation, Brussels, Belgium.

International Dairy Federation. 1989. Milk fat Products and Butter. Determination of Fat Acidity. IDF Standard 6B. International Dairy Federation, Brussels, Belgium.

International Dairy Federation. 1993. Milk. Determination of the nitrogen (Kjeldahl method) and calculation of the crude protein content. IDF Standard 20B. International Dairy Federation, Brussels, Belgium.

Jarrett, W. D., J. W. Aston, and J. R. Dulley. 1982. A simple method for estimating free amino acids in Cheddar cheese. Aust. J. Dairy Technol. 37:55-58.

Kandarikis, I. G., G. A. Moatsou, A. I. K. Georgala, S. Kaminarides, and E. Anifantakis. 2001. Effect of draining temperature on the biochemical characteristics of Feta cheese. Food Chem. 72:369_ 378.

Karakus, M., and I. Alperden. 1995. Effect of starter composed of various species of lactic acid bacteria on quality and ripening of
Turkish white pickled cheese. Lebensm. Wiss. Technol. 28:404-409.

Karakus, M., M. Borcakli, and I. Alperden. 1992. Beyaz peynirinin olgunlasmasi surecinde laktik asit bakterileri. Gida 17:363-369. [In Turkish]

Katsiari, M. C., E. Alichanidis, L. P. Voutsinas, and I. G. Roussis. 2000. Proteolysis in reduced sodium Feta cheese made by partial substitution of $\mathrm{NaCl}$ by KCl. Int. Dairy J. 10:635-646.

Kawabata, S., L. Vassal, D. Le Bars, B. Cesselin, M. Nardi, J.-C. Gripon, and M.-P. Chapot-Chartier. 1997. Phage-induced lysis of Lactococcus lactis during Saint-Paulin cheese ripening and its impact on proteolysis. Lait 77:229-239.

Kilic, S., S. Gonc, H. Uysal, and C. Karagozlu. 1998. Geleneksel yontemle ve kultur kullanilarak yapilan Izmir Tulum peynirinin olgunlasma suresinde meydana gelen degisikliklerin kiyaslanmasi. Pages 43-64 in 5. Sut ve Sut Urunleri Sempozyumu, Trakya Univ. Ziraat Fakultesi, Tekirdag, Turkey. [In Turkish]

Kuchroo, C. N., and P. F. Fox. 1982. Soluble nitrogen in cheddar cheese: Comparison of extraction procedures. Milchwissenschaft 37:331-335.

Lane, C. N., and P. F. Fox. 1996. Contribution of starter and adjunct lactobacilli to proteolysis in Cheddar cheese during ripening. Int. Dairy J. 6:715-728.

Lane, C. N., and P. F. Fox. 1997. Role of starter enzymes during ripening of Cheddar cheese made from pasteurised milk under controlled microbiological conditions. Int. Dairy J. 7:55-63.

Lau, K. Y., D. M. Barbano, and R. R. Rasmussen. 1991. Influence of pasteurization of milk on protein breakdown in Cheddar cheese during aging. J. Dairy Sci. 74:727-740.

Law, J., G. F. Fitzgerald, C. Daly, P. F. Fox, and N. Y. Farkye. 1992. Proteolysis and flavour development in Cheddar cheese made with the single strains Lactococcus lactis ssp. lactis UC317 or Lactococcus lactis ssp. cremoris HP. J. Dairy Sci. 75:1173-1185.

Lawrence, R. C., L. K. Creamer, and J. Gilles. 1987. Texture development during cheese ripening. J. Dairy Sci. 70:1748-1760.

Lee, K. D., C. G. Lo, and J. J. Warthesen. 1996. Removal of bitterness from the bitter peptides extracted from Cheddar cheese with peptidases from Lactococcus lactis subsp. cremoris SK11. J. Dairy Sci. 79:1521-1528.

Litopoulou-Tzanetaki, E., N. Tzanetakis, and A. Vafopoulou-Mastrojiannaki. 1993. Effect of the type of lactic starter on microbiological, chemical and sensory characteristics of Feta cheese. Food Microbiol. 10:31-41.

Lynch, C. M., P. L. H. McSweeney, P. F. Fox, T. M. Cogan, and F. D. Drinan. 1997. Contribution of starter lactococci and non-starter lactobacilli to proteolysis in cheddar cheese with a controlled microflora. Lait 77:441-459.

Madkor, S. A., P. S. Tong, and M. El-Soda. 2000. Ripening of Cheddar cheese with added attenuated adjunct cultures of lactobacilli. J. Dairy Sci. 83:1684-1691.

McSweeney, P. L. H., P. F. Fox, J. A. Lucey, K. N. Jordan, and T. M. Cogan. 1993. Contribution of indigenous microflora to the maturation of Cheddar cheese. Int. Dairy J. 3:613-634.

McSweeney, P. L. H., S. Pochet, P. F. Fox, and A. Healy. 1994. Partial identification of peptides from the water-soluble fraction of Cheddar cheese. J. Dairy Res. 61:587-590.

McSweeney, P. L. H., and M. J. Sousa. 2000. Biochemical pathways for the production of flavour compounds in cheeses during ripening: A review. Lait 80:293-324.

Michaelidou, A., E. Alichanidis, H. Urlaub, A. Polychroniadou, and G. K. Zerfiridis. 1998. Isolation and identification of some major water-soluble peptides in Feta cheese. J. Dairy Sci. 81:3109-3116.

Moatsou, G. A., I. G. Kandarikis, A. K. Georgala, E. S. Alichanidis, and E. M. Anifantakis. 1999. Effect of starters on proteolysis of Graviera Kritis cheese. Lait 79:303-315.

Nunez, M., C. Garcia-Aser, M. A. Rodriguez-Martin, M. Medina, and P. Gaya. 1986. The effect of ripening and cooking temperatures on proteolysis and lipolysis in Manchego cheese. Food Chem. $21: 115-123$

O'Keeffe, R. B., P. F. Fox, and C. Daly. 1976. Contribution of rennet and starter proteases to proteolysis in Cheddar cheese. J. Dairy Res. 43:97-107. 
Pappa, H. C., and E. M. Anifantakis. 2001. Effect of concentrated starter cultures on the proteolysis and organoleptic characteristics of Feta cheese. Milchwissenschaft 56:325-329.

Pappas, C. P., E. Kondyli, L. P. Voutsinas, and H. Mallatou. 1996. Effect of starter level, draining time and ageing on the physicochemical, organoleptic and rheological properties of Feta cheese. J. Soc. Dairy Technol. 49:73-78.

Polychroniadou, A., A. Michaelidou, and N. Paschaloudis. 1999. Effect of time, temperature and extraction method on the trichloroacetic acid-soluble nitrogen of cheese. Int. Dairy J. 9:559-568.

Poveda, J. M., M. J. Sousa, L. Cabezas, and P. L. H. McSweeney. 2003. Preliminary observation proteolysis in Manchego cheese made with a defined-strain starter culture and adjunct starter (Lactobacillus plantarum) or a commercial starter. Int. Dairy J. 13:169-178.

Powell, I. B., M. C. Broome, and G. K. Y. Limsowtin. 2002. Starter cultures: General aspects. Pages 261-268 in Encyclopedia of Dairy Science. H. Roginski, J. W. Fuquay, and P. F. Fox, ed. Academic Press, London, UK.

Pripp, A. H., Shakeel-Ur-Rehman, P. L. H. McSweeney, T. Sorhaug, and P. F. Fox. 1999. Multivariate statistical analysis of peptide profiles and free amino acids to evaluate effects of single-strain starters on proteolysis in miniature Cheddar-type cheeses. Int. Dairy J. 9:473-479.

Rampilli, M., P. M. Toppino, V. Raja, and A. Daghetta. 1997. Cheese ripening: Evaluation of $\mathrm{pH} 4.6$ soluble peptidic fraction by $\mathrm{RP}$ HPLC. Food Sci. Technol. Abstr. 79:269.

Rank, T. C., R. Grappin, and N. F. Olson. 1985. Secondary proteolysis of cheese during ripening: A review. J. Dairy Sci. 64:801-805.

Romeih, E. A., A. Michaelidou, C. G. Biliaderis, and G. K. Zerfiridis. 2002. Low-fat white-brined cheese made from bovine milk and two commercial fat mimetics: Chemical, physical and sensory attributes. Int. Dairy J. 12:525-540.

Saldamli, I., and M. Kaytanli. 1998. Utilisation of Fromase, Maxiren and Rennilase as alternative coagulating enzymes to rennet in Turkish White cheese. Milchwissenschaft 53:22-25.
SAS Institute. 1995. User's Guide: Statistics, Version 6.12 edition. SAS Inst., Inc., Cary, NC.

Shakeel-Ur-Rehman, A. H. Pripp, P. L. H. McSweeney, and P. F. Fox. 1999. Assessing the proteolytic and cheese ripening properties of single strains of Lactococcus in miniature cheeses. Lait 79:361-383.

Shalabi, S. I., and P. F. Fox. 1987. Electrophoretic analysis of cheese, comparison of methods. Irish J. Food Sci. Technol. 11:135-151.

Tan, P. S. T., B. Poolman, and W. N. Konings. 1993. Proteolytic enzymes of Lactococus lactis. J. Dairy Res. 60:269-286.

Turk Standartlari Enstitusu (TSE). 1995. Beyaz peynir. TS 591. Turk Standartlari Enstitusu, Ankara, Turkey.

Tzanetakis, N., A. Vafopoulou-Mastrojiannaki, and E. LitopoulouTzanetaki. 1995. The quality of white-brined cheese from goat's milk made with different starters. Food Microbiol. 12:55-63.

Ucuncu, M. 1981. Inek ve koyun sutlerinden imal edilen Beyaz peynirlerde olgunlasma surecindeki serbest amino asit birikiminin belirlenmesi. Ege Universitresi Gida Fakultesi Dergisi 2:1-36. [In Turkish]

Urbach, G. 1993. Relationship between cheese flavour and chemical composition. Int. Dairy J. 3:389-422.

Urbach, G. 1997. The flavour of milk and dairy products. II. Cheese: Contribution of volatile compounds. Int. J. Dairy Technol. 50:79-89.

Visser, F. M. W. 1977a. Contribution of enzymes from rennet, starter bacteria and milk to proteolysis and flavour development in Gouda cheese. 2. Development of bitterness and cheese flavour. Neth. Milk Dairy J. 31:247-264.

Visser, F. M. W. 1977b. Contribution of enzymes from rennet, starter bacteria and milk to proteolysis and flavour development in Gouda cheese. 3. Protein breakdown: analysis of the soluble nitrogen and amino acid nitrogen fractions. Neth. Milk Dairy J. 31:210-239.

Visser, S. 1993. Proteolytic enzymes and their relation to cheese ripening and flavor. An overview. J. Dairy Sci. 76:329-350. 